\title{
Punitive Damages and the Eighth Amendment: An Analytical Framework for Determining Excessiveness
}

This Comment argues that the eighth amendment's excessive fines clause should be held to limit state imposition of punitive damages in civil actions. The author considers and rejects the "formal" approach to the eighth amendment, which would restrict application of the excessive fines clause to criminal prosecutions. Applying instead the more "functional" approach employed by the Supreme Court in analogous contexts, the author finds that punitive damages are the functional equivalent of fines and therefore should be subject to similar limitations. The Comment then explores the meaning of "excessive" through judicial and academic analysis of the history of the excessive fines clause. The essential principle underlying the eighth amendment is proportionality: The harshness of a penalty should be proportional to the gravity of the offense for which it is imposed. The guidelines identified by the Supreme Court in Solem v. Helm provide a framework for evaluating the constitutional adequacy of the standards by which states currently determine the magnitude of punitive damage awards. Adapting and applying these guidelines, this Comment concludes that prevailing standards do not adequately protect defendants against excessive punitive awards.

\section{INTRODUCTION}

Punitive damage awards are an increasingly visible-and controversial-phenomenon in contemporary civil litigation. Both the number and size of such assessments have increased markedly in the past several years. ${ }^{1}$ Are there any constitutional limits to the size of punitive damage awards? The United States Supreme Court is presently reviewing a decision of the Mississippi Supreme Court, Bankers Life \& Casualty Co. v. Crenshaw, ${ }^{2}$ which upheld a punitive damage award of $\$ 1.6$ million for bad faith refusal to pay an insurance claim. The key issue presented for

1. M. Peterson, Punitive Damages: Preliminary Empirical Findings 8, 44 (1985) (Institute for Civil Justice studies "confirm the widespread perception that punitive awards have become both more frequent and larger in recent years"); Jeffries, $A$ Comment on the Constitutionality of Punitive Damages, 72 VA. L. REV. 139, 143-45 (1986) (noting a "sudden upsurge of punitive damage claims" of $\$ 1$ million or more); Owen, Problems in Assessing Punitive Damages Against Manufacturers of Defective Products, 49 U. CHI. L. REV. 1, 3-6 (1982) (documenting the increasing size of punitive damage awards between 1976 and 1982).

2. 483 So. 2d 254 (Miss. 1985), prob. juris. noted, 107 S. Ct. 1367 (1987) (No. 85-1765). 
review is whether the size of the punitive award, which is eighty times greater than the compensatory award, violates the eighth amendment's prohibition against the imposition of "excessive fines." 3 Bankers Life affords the Court an opportunity to explore this uncharted territory.

This Comment argues that the excessive fines clause imposes a constitutional upper limit on the size of punitive damage awards. Part I provides a brief overview of both the history of punitive damages and the existing state and federal laws governing such awards. Part II traces the doctrinal development of the excessive fines clause and argues that it applies to civil punitive damage awards. ${ }^{4}$ Part III identifies the fundamental principles by which laws governing punitive awards should be judged, and Part IV assesses the extent to which prevailing state practices fail to accord with the proposed constitutional standards.

\section{I}

\section{Punitive Damages}

Imposing multiple damages for wrongs committed against others is an ancient practice. Its roots have been traced to the Code of Hammurabi, the Bible, and classical Roman law. ${ }^{5}$ At least as early as the 13th century, English law accepted the practice as a substitute for criminal "presentments" brought in local courts or before the king's jus-

3. "Excessive bail shall not be required, nor excessive fines imposed, nor cruel and unusual punishments infiicted." U.S. CONST. amend. VIII. The applicability of the excessive fines clause to punitive damages was first argued and briefed the previous term. Aetna Life Ins. Co. v. Lavoie, 106 S. Ct. 1580 (1986). In Aetna, the judgment of the Alabama Supreme Court, including a punitive damage award of $\$ 3.5$ million, was vacated on other grounds, but the Court noted that arguments regarding the constitutional status of punitive damages "raise important issues which, in an appropriate setting, must be resolved." Id. at 1589 .

The Court may again decline to reach the eighth amendment issue in Bankers Life; the policyholder has asserted that the insurer's failure to raise the issue below deprives the Supreme Court of jurisdiction. Arguments Before the Court, 56 U.S.L.W. 3423, 3424 (U.S. Dec. 22, 1987) (summarizing oral arguments presented Nov. 30, 1987). As an alternative to the excessive fines argument, Bankers Life is challenging the punitive damage award under the due proeess clause, arguing that bad faith failure to settle a claim was not recognized as giving rise to such sanctions at the time of the conduct. Id. at 3423. The insurer is also urging the Court to strike down on equal protection grounds a Mississippi statute mandating an automatic penalty for unsuceessful defense appeals. Id. For further discussion of the arguments presented to the Court, see Geller \& Levy, The Constitutionality of Punitive Damages, A.B.A. J., Dec. 1, 1987, at 88; Does 8th Amendment Apply to Punitive Damages?, Nat'1 L.J., Dec. 14, 1987, at 5, col. 1.

4. This Comment relies, especially in its analysis of the arguments for applying the excessive fines clause to punitive damages, on an excellent article by Professor Jeffries. See Jeffries, supra note 1. This Comment, in effect, extends Professor Jeffries' analysis by proposing standards for determining when a punitive damage award is excessive. See id. at 158 (acknowledging need for such standards).

5. K. Redden, Punitive Damages $\$ 2.2(A)(1)$, at 24 (1980). For a description of the penal character of civil damages imposed in preclassical and classical Rome, see B. NiCHOLAS, AN INTRODUCTION TO ROMAN LAW 209-10, 217 (1962). 
tices. ${ }^{6}$ In lieu of state prosecution, a nonfelony offender could be punished with double or treble damages in civil actions brought by the victim, thus giving the injured party more incentive than royal officials to bring the malefactor to justice. ${ }^{7}$

With the growth of the jury system, multiple damages evolved into penal damages awarded at the jury's discretion. The punitive rationale for these discretionary awards was first articulated in 1763, as a judicial justification for the English courts' reluctance to set aside jury verdicts that were clearly in excess of actual damages. ${ }^{8}$ Introduced into the United States in the late eighteenth century, ${ }^{9}$ punitive damages have since been justified as serving a wide range of functions, from compensating for otherwise uncompensable losses to deterring oppressive business practices. ${ }^{10}$ In the majority of jurisdictions that currently allow such awards, ${ }^{11}$ pumitive damages are seen primarily as fulfilling two interrelated purposes: punishment of the defendant for egregious conduct of some sort, and deterrence of the defendant or others from engaging in similar behavior in the future. ${ }^{12}$

6. 2 F. Pollock \& F.W. Maitland, The History of ENGlish Law 522 (2d. ed. 1898), "Presentments" were official accusations of nonfelony offenses, which could result in either imprisonment or "amercements" (money payments similar to fines). Id. at 512-13.

7. Id. at 522. Punitive damages are now extremely rare in Great Britain, and virtually unknown in civil law countries. J. Fleming, The American System in International Perspective 16 (1987) (unpublished manuscript) (on file with the California Law Review).

8. Huckle v. Money, 2 Wils. K.B. 205, 95 Eng. Rep. 768 (1763); see K. RedDEN, supra note $5, \S 2.2(\mathrm{~A})(2)$, at 26 .

9. K. REDDEN, supra note 5, § 2.3(B), at 32 (citing Coryell v. Colbaugh, 1 N.J.L. 77 (1791) (action for breach of promise to marry)).

10. K. REDDEN, supra note $5, \S 2.2$, at $28-31$ (punitive damages historically defended as compensating for mental anguish and other intangible harms, deterring wrongdoers, redressing unequal criminal punishments, and providing an outlet for revenge); Ellis, Fairness and Efficiency in the Law of Punitive Damages, 56 S. CAL. L. REv. 1, 3-12 (1982) (purposes of punitive damages have been punishing the defendant, deterring defendant and others, preserving the peace, inducing private law enforcement, compensating for noncompensable losses, and paying attorneys' fees); Levine, Demonstrating and Preserving the Deterrent Effect of Punitive Damages in Insurance Bad Faith Actions, 13 U.S.F. L. REv. 613 (1979) (punitive damages reform unfair insurance claims practices); Owen, Punitive Damages in Products Liability Litigation, 74 MicH. L. Rev. 1257 (1976) (punitive damages should punish and deter the marketing of defective products).

11. Only four states expressly prohibit common law punitive damage awards: Louisiana, Massachusetts, Nebraska, and Washington. See McCoy v. Arkansas Natural Gas Co., 175 La. 487, 498, 143 So. 383, 385-86 (no punitive damages without statutory authorization), cert. denied, 287 U.S. 661 (1932); City of Lowell v. Massachusetts Bonding \& Ins. Co., 313 Mass. 257, 269, 47 N.E.2d 265, 272 (1943) (no punitive damages unless expressly authorized by statute); Abel v. Conover, 170 Neb. 926, 104 N.W.2d 684 (1960) (state constitution prohibits punitive damages); Spokane Truck \& Dray Co. v. Hoefer, 2 Wash. 45, 25 P. 1072 (1891) (rejecting punitive damages as duplicative and oppressive); see also $1 \mathrm{~J}$. Ghiardi \& J. Kircher, Punitive Damages: LaW and Practice $\S \S 4.07-12$ (1985 \& Supp. 1986) (discussing jurisdictions that totally or partially forbid punitive damage awards).

12. J. GHIARDI \& J. KIRCHER, supra note $11, \S 4.14$. Although punitive damages are often defended as necessary "to reward a plaintiff for public service in bringing the wrongdoer to account," Bankers Life and Casualty Co. v. Crenshaw, 483 So. 2d 254, 269 (Miss. 1985), prob. juris. 
Liability for punitive damages is generally predicated on a finding of malicious intent or reckless indifference to the rights and safety of others. ${ }^{13}$ While intentional harm will support an award of punitive damages in virtually every state allowing such awards, ${ }^{14}$ there is less unanimity as to the degree of fault required to impose them for unintentional injuries. ${ }^{15}$ Originally limited to malicious tort actions involving physical injury or defamation, ${ }^{16}$ punitive damages are nowadays becoming available in many other types of actions, ${ }^{17}$ including civil rights violations, ${ }^{18}$ products hability, ${ }^{19}$ wrongful termination, ${ }^{20}$ bad faith breach of con-

noted, 107 S. Ct. 1367 (1987) (No. 85-1765), such a justification is closely related to the interests in punishment and deterrence. See Ellis, supra note 10, at 10.

The Supreme Court has recognized that pumitive damages are "not compensation for injury. Instead, they are private fines levied by civil juries to pumish reprehensible conduct and to deter its future oceurrence." Gertz v. Robert Welch, Inc., 418 U.S. 323, 350 (1974). Nevertheless, three states-Connecticut, Michigan, and New Hampshire-apply the label "punitive" or "exemplary" to damage awards that are primarily compensatory in nature. 1 J. GHIARDI \& J. KIRCHER, supra note 11, $\S 4.03,4.05$, 4.06; see Collens v. New Canaan Water Co., 155 Conn. 477, 488, 234 A.2d 825, 831-32 (1967) ("punitive damages" recoverable only as compensation for litigation expenses); Jackovich v. General Adjustment Bureau, Inc., 119 Mich. App. 221, 234, 326 N.W.2d 458, 464 (1982) (exemplary damages proper only as compensation for humiliation, outrage, or indignity); Vratsenes v. New Hampshire Auto, Inc., 112 N.H. 71, 289 A.2d 66 (1972) (aggravated conduct may justify additional compensation for "vexation and distress"). Some commentators advocate this practice, arguing that compensatory damages are an unreliable measure of actual harm to the plaintiff. They see punitive damages as a supplement to the compensatory award, ensuring the plaintiff's complete reparation. See, e.g., Owen, supra note 10, at 1295-99. This argument, as it relates both to legal costs and to compensation for loss of familial relationships, is countered forcefully by Professor Epstein, who argues that such goals should be accomplished directly: "The well-tailored remedy is preferable to the overbroad one." R. EPSTEIN, ModERn Products LIABILITY LAW 177-78 (1980). To the extent that punitive damages serve compensatory ends, they are no more "punitive" than other awards, and do not raise the constitutional issues to which this Comment is addressed.

13. The Restatement uses a standard of "outrageousness," defined as conduct founded on "evil motive ... or reckless indifference to the rights of others." RESTATEMENT (SECOND) OF TORTS $\S 908$ comment b (1979). The standard established by statute in California requires "oppression, fraud, or malice." Cal. Civ. CoDE $\S 3294$ (West Supp. 1988).

14. See K. REDDEN, supra note $5, \S 2.1$, at 23 .

15. The validity of the various standards for punitive damages liability has been the subject of considerable controversy. See Ellis, supra note 10, at 33-53; Comment, Formulating Standards for Awards of Punitive Damages in the Borderland of Contract and Tort, 74 CALIF. L. REv. 2033 (1986). Except as they affect the appropriate size of an award, the standards for assessing punitive damages in particular situations are not addressed by this Comment.

16. See Ellis, supra note 10, at 14-15 (citing English cases decided between 1655 and 1818).

17. See sources cited supra note 1; see also Mallor \& Roberts, Punitive Damages: Toward a Principled Approach, 31 Hastings L.J. 639, 639-40 (1980); Note, The Imposition of Punishment by Civil Courts: A Reappraisal of Punitive Damages, 41 N.Y.U. L. REv. 1158, 1158 (1966).

18. See, e.g., City of Newport v. Fact Concerts, Inc., 453 U.S. 247 (1981); Zarcone v. Perry, 572 F.2d 52 (2d Cir. 1978).

19. See, e.g., Grimshaw v. Ford Motor Co., 119 Cal. App. 3d 757, 174 Cal. Rptr. 348 (1981); Palmer v. A.H. Robins Co., 684 P.2d 187 (Colo. 1984).

20. See, e.g., Rawson v. Sears, Roebuck \& Co., 615 F. Supp. 1546 (D. Colo. 1985) (\$10 million punitive damages for wrongful termination due to age discrimination), rev'd on other grounds, 822 F.2d 908 (10th Cir. 1987) (no private right of action for age discrimination under Colorado law). 
tract, $^{21}$ and interference with contractual relations. ${ }^{22}$

Jurisdictions vary in their approaches to determining the appropriate size of punitive damages. ${ }^{23}$ California is fairly typical, presenting to a jury three factors for consideration: (1) the reprehensibility of the defendant's conduct; (2) the amount of coinpensatory damages awarded; and (3) the wealth of the defendant. ${ }^{24}$ Several states impose considerably less restraint on the jury's discretion. Mississippi, for example, determines the size of such awards by reference to "general factors," which include: (1) the amount necessary to punish and deter the defendant; (2) the amount necessary "to make an example of the defendant" to deter others; and (3) the wealth of the defendant. ${ }^{25}$ In all jurisdictions, a punitive dainage award can be set aside if it resulted from jury "passion or prejudice." 26

With the drastic increase in the size and number of pumitive judgments in the past two decades, ${ }^{27}$ criticism of such awards as unjustified and even unconstitutional has flourished. Some coinmentators argue that punitive damages have outhived their original purposes, and that

21. See, e.g., Neal v. Farmers Ins. Exch., 21 Cal. 3d 910, 582 P.2d 980, 148 Cal. Rptr. 389 (1978); Bankers Life \& Casualty Co. v. Crenshaw, 483 So. 2d 254 (Miss. 1985), prob. juris. noted, 107 S. Ct. 1367 (1987) (No. 85-1765).

22. See, e.g., Texaco, Inc. v. Pennzoil Co., 729 S.W.2d 768, 863, 865 (Tex. Ct. App. 1987); Seaman's Direct Buying Serv., Inc. v. Standard Oil Co., 36 Cal. 3d 752, 686 P.2d 1158, 206 Cal. Rptr. 354 (1984).

23. See generally Annotation, Excessiveness or Inadequacy of Punitive Damages Awarded in Personal Injury or Death Cases, 35 A.L.R.4th 441 (1985); Annotation, Excessiveness or Inadequacy of Punitive Damages in Cases Not Involving Personal Injury or Death, 35 A.L.R.4th 538 (1985).

24. See Neal, 21 Cal. 3d at 928, 582 P.2d at 990, 148 Cal. Rptr. at 399; see also infra notes 19293 and accompanying text; $c f$. RESTATEMENT (SECOND) OF TORTS § 908 (1979) ("In assessing punitive damages, the trier of fact can properly consider the character of the defendant's act, the nature and extent of the harm to the plaintiff that the defendant caused or intended to cause and the wealth of the defendant.").

25. Bankers Life, 483 So. $2 \mathrm{~d}$ at 278 . The Mississippi court will not interfere with the jury's award unless it is so large as to "shock the judicial conscience." Id.; see infra notes 148-52 and accompanying text.

26. Jury passion or prejudice is, of course, ground for reversal of any award, whether compensatory or punitive. See Curtis Publishing Co. v. Butts, 388 U.S. 130, 160 (1967) (plurality opinion). Some courts have indicated that the size of a punitive award may warrant a presumption of passion or prejudice. See, e.g., Little v. Stuyvesant Life Ins. Co., 67 Cal. App. 3d 451, 469, 136 Cal. Rptr. 653, 663 (1977) (punitive damages amounting to $15 \%$ of defendant's net worth were so disproportionate as to suggest passion and prejudice); Riegel v. Aastad, 272 A.2d 715, 717-18 (Del. 1970) (sheer size of $\$ 60,000$ punitive damage award warranted the inference of jury passion or prejudice); Safeco Ins. Co. v. Ellinghouse, 725 P.2d 217 (Mont. 1986) (presumption of passion or prejudice in $\$ 5$ million punitive award justified reduction to $\$ 775,000)$; Timmons v. Royal Globe Ins. Co., 653 P.2d 907 (Okla. 1982) (\$3 million punitive award reduced by one-half because record showed likelihood of improper jury response to evidence).

27. See K. REDDEN, supra note 5, at 1 (Supp. 1986) (observing an "ever-growing number of cases in which the plaintiff sought punitive damages"); see also supra notes 1 \& 17. But see Daniels, Punitive Damages: The Real Story, A.B.A. J., Aug. 1, 1986, at 60, 60 (preliminary findings of an American Bar Foundation study indicate that punitive damage awards are "not routine [and] not, typically, given in amounts that boggle the mind"). 
with the tremendous expansion of compensable losses, such awards constitute an unjustified windfall to an already fully compensated plaintiff. ${ }^{28}$ Others urge that because punitive damage awards serve the penal functions of punishment and deterrence, they should be subject to the protective procedures applicable to criminal actions. ${ }^{29}$ Still others fear that successive large punitive awards against manufacturers may jeopardize the availability of compensation for other victims of the same conduct, ${ }^{30}$ and that the increasing number and size of punitive awards threaten the economic stability of American industry. ${ }^{31}$ Finally, some believe that existing standards for review of jury awards are inadequate, ${ }^{32}$ and that the eighth amendment's excessive fines clause or the "fundamental fairness" doctrine of due process should provide a constitutional limit on the size of punitive damage awards. ${ }^{33}$

The United States Supreme Court has never directly confronted the constitutional status of massive punitive damage awards or the adequacy of the standards by which courts review them. The Court's first reference to the imposition of such a remedy in civil actions was a rather offhanded presumption of the doctrine's validity in $1851 .^{34}$ Consistent with this presumption, the Court has never reversed an award of punitive damages as unconstitutionally excessive. ${ }^{35}$ Nevertheless, questions of the

28. See, e.g., Sales \& Cole, Punitive Damages: A Relic That Has Outlived Its Usefulness, 37 VAND. L. REV. 1117, 1118 (1984) ("The desire to inflict punishment ... represents an insupportable basis for awarding quasi-criminal fines in a civil context ....").

29. See, e.g., Grass, The Penal Dimensions of Punitive Damages, 12 Hastings Const. L.Q. 241 (1985); Wheeler, The Constitutional Case for Reforming Punitive Damages Procedures, 69 VA. L. REV. 269 (1983); Note, supra note 17, at 1170; see also Comment, Criminal Safeguards and the Punitive Damages Defendant, 34 U. CH1. L. REV. 408 (1967) (suggesting the adoption of some, but not all, criminal trial safeguards in punitive damage actions).

30. See, e.g., Jackson v. Johns-Manville Sales Corp., 727 F.2d 506, 524-25 (5th Cir. 1984) (Clark, C.J.), vacated in part on reh'g en banc, 750 F.2d 1314 (1985); Roginsky v. RichardsonMerrell, Inc., 378 F.2d 832, 841 (2d Cir. 1967) (Friendly, J.).

31. See Owen, supra note 1, at 6; Seltzer, Punitive Damages in Mass Tort Litigation: Addressing the Problems of Fairness, Efficiency and Control, 52 FORDHAM L. REV. 37, 92 (1983).

32. See Ellis, supra note 10 , at 52-53.

33. See Jeffries, supra note 1, at 140; Note, The Constitutionality of Punitive Damages Under the Excessive Fines Clause of the Eighth Amendment, 85 MicH. L. REv. 1699 (1987).

34. Day v. Woodworth, 54 U.S. (13 How.) 362, 370-71 (1851) (dictum) ("repeated judicial decisions for more than a century" are presumptively valid; propriety of punitive damage awards "will not admit of argument").

35. The Court has recognized that "[p]unitive damages have long been a part of traditional state tort law." Silkwood v. Kerr-McGee Corp., 464 U.S. 238, 255 (1984); see also City of Newport v. Fact Concerts, Inc., 453 U.S. 247, 269 (1981) (availability of punitive damages against public officials for civil rights violations "directly advances the public's interest in preventing repeated constitutional deprivations"); Curtis Publishing Co. v. Butts, 388 U.S. 130, 159 (1967) (plurality opinion) ("the Constitution presents no general bar to the assessment of punitive damages in a civil case").

The Court has prohibited, on federal statutory grounds, punitive awards against municipalities, City of Newport v. Fact Concerts, Inc., 453 U.S. 247 (1981), and labor unions, International Bhd. of Elec. Workers v. Foust, 442 U.S. 42 (1979). 
permissible scope and size of punitive damage awards continue to surface, ${ }^{36}$ and in Aetna Life Insurance Co. v. Lavoie, ${ }^{37}$ the Court acknowledged that these questions are not yet resolved. Bankers Life provides an opportunity to address the constitutional status of punitive damages in a contemporary context. ${ }^{38}$

II

\section{The SCope of The EXCessive Fines Clause}

The applicability of the eighth amendment's excessive fines clause to punitive damages awarded in civil actions is an issue of first impression. ${ }^{39}$ Indeed, the interpretation of the excessive fines clause in any context is uncharted territory; there is almost no case law on point. The few Supreme Court cases involving the eighth amendment have focused on the "cruel and unusual punishments" clause. ${ }^{40}$ The analysis must therefore proceed by analogy, emphasizing the primciples underlying the constitutional protections.

The scope of the excessive fines clause can be analyzed through three distinct but related questions, none of which have definitive answers in the cases construmg the eighth amendment. ${ }^{41}$ These questions are:

(1) Does the prohibition of excessive fines apply to the states as well as to the federal government? Section $A$ answers yes.

(2) Is the application of the excessive fines clause limited to actions

36. See, e.g., Eleetrical Workers, 442 U.S. at 50,51 n.14 (broad jury discretion in awarding punitive damages makes the impact of such "windfall recoveries ... unpredictable" and subject to being used "to punish unpopular defendants"); Gertz v. Robert Welch, Inc., 418 U.S. 323, 350 (1974) ("jury discretion to award punitive damages unnecessarily exacerbates the danger of media self-censorship").

Dissenting opinions by both Justices Brennan and Rehnquist in recent years have expressed serious reservations about the continued vitality of punitive damages. See Dun \& Bradstreet, Inc. v. Greenmoss Builders, Inc., 105 S. Ct. 2939, 2964 (1985) (Brennan, J., dissenting) (deterrence interest likely outweighed by social costs in media libel action); Smith v. Wade, 461 U.S. 30, 59 (1983) (Rehnquist, J., dissenting) (punitive damages imposed in a civil action should go to state, not to fully compensated plaintiff).

37. 106 S. Ct. 1580,1589 (1986); see supra note 3.

38. Bankers Life and Casualty Co. v. Crenshaw, 483 So. 2d 254, 269 (Miss. 1985), prob. juris. noted, 107 S. Ct. 1367 (1987) (No. 85-1765); see supra notes 2-3 and accompanying text.

39. See N.Y. Times, Mar. 10, 1987, at 28, col. 1 (discussing "defendants' novel constitutional argument in Bankers Life"). The novelty of the argument was recognized by both parties in Aetna. See Appellant's Jurisdictional Statement at 29, Appellee's Motion to Dismiss at 25, Aetna Life Ins. Co. v. Lavoie, 106 S. Ct. 1580 (1986) (No. 84-1601) (BNA microfiche).

40. See, e.g., Solem v. Helm, 463 U.S. 277 (1983); Robinson v. California, 370 U.S. 660 (1962); Trop v. Dulles, 356 U.S. 86 (1958); Weems v. United States, 217 U.S. 349 (1910).

41. Each of these questions has recently been addressed by Professor Jeffries, who concludes that the excessive fines clause should be held to govern punitive damage awards. See Jeffries, supra note 1, at 147-51. The discussion in this Part is guided to a large extent by Professor Jeffries's article, although my analysis devotes more attention to countering the "formal" argument that the eighth amendment applies exclusively to penalties imposed in criminal actions. 
formally identified as "criminal," or is the protection triggered by a functional determination of the "penal" nature of the sanction? Section B argues for the functional approach.

(3) Should punitive damages be considered the functional equivalent of fines, so as to fall within the scope of the excessive fines clause? Section $\mathrm{C}$ so contends.

\section{A. Its Application to the States}

Although the Supreme Court has never expressly held the excessive fines clause applicable to the states, it has held that the cruel and unusual punishments clause, through the fourteenth amendment, limits the states' authority to impose capital punishment, ${ }^{42}$ prison sentences, ${ }^{43}$ and other forms of pumshment. ${ }^{44}$ The Court has also recognized that the eighth amendment imposes "parallel limitations" fines, and other pumshments. ${ }^{46}$ Therefore, by analogy to the cruel and unusual pumshment clause, the excessive fines clause applies to the states. $^{47}$

This conclusion is further supported by the Court's rationale for incorporatimg specific provisions of the Bill of Rights into the fourteenth amendment's due process clause. The Court has focused on whether the principle is "so rooted in the tradition and conscience of our people as to be ... fundamental"48 or "basic [to] our system of jurisprudence."49 The history of the principle articulated in the excessive fines clause testifies to its roots in our "tradition and conscience." 50 Professor Jeffries argues persuasively that, since the imposition of excessive punitive awards vio-

42. Enmund v. Florida, 458 U.S. 782 (1982); Coker v. Georgia, 433 U.S. 584 (1977); Furman v. Georgia, 408 U.S. 238 (1972).

43. Solem v. Helm, 463 U.S. 277 (1983); Robinson v. California, 370 U.S. 660 (1962).

44. Hutto v. Finney, 437 U.S. 678, 682-83 (1978) (confinement in "punitive isolation," improper diet, other prison conditions); Estelle v. Gamble, 429 U.S. 97, 104 (1976) ("deliberate indifference to serious medical needs of prisoners").

45. Ingraham v. Wright, 430 U.S. 651,664 (1977).

46. The three clauses have been linked since at least 1689 , when they were written into the English Bill of Rights. See Solem, 463 U.S. at 285 n.10 (tracing the language of the eighth amendment from the English Bill of Rights (1689) through the Virginia Declaration of Rights (1776)). The Court discovered the principle underlying the eighth amendment in the Magna Carta's prohibition of excessive "amercements"-monetary penalties similar to modern day fines. Id. at 284 \& nn.8-9; see also Massey, The Excessive Fines Clause and Punitive Damages: Some Lessons from History, 31 VAND. L. REV. 1233, 1240-69 (1987) (comprehensive listory of the prohibition of excessive fines and amercements in English law).

47. J. Nowak, R. Rotunda \& J. Young, American Constitutional Law 317, 366 (3d ed. 1986). The Court has assumed, without explicitly deciding, that the excessive bail clause applies to the states. See Schilb v. Kuebel, 404 U.S. 357, 365 (1971).

48. Palko v. Connecticut, 302 U.S. 319, 325 (1937) (Cardozo, J.).

49. In re Oliver, 333 U.S. 257, 273 (1949); see also Duncan v. Louisiana, 391 U.S. 145, 150 n.14 (1968) (fundamental provisions are those "necessary to an Anglo-American regime of ordered liberty").

50. See supra note 46 . 
lates "fundamental fairness," the prohibition is encompassed by the fourteenth amendment's mandate of due process of law. ${ }^{51}$

\section{B. Its Application to "Civil" Actions}

Whether the excessive fines clause applies to sanctions imposed in civil actions is a more troublesome question. Two parallel, competing traditions in eighth amendment jurisprudence lead to quite different answers. Throughout this discussion, I refer to these two traditions as the "formal" approach and the "functional" approach.

The formal approach is exemplified by Ingraham v. Wright, ${ }^{52}$ where the Supreme Court held that the cruel and unusual punishments clause does not apply to corporal pumshment im public schools. The holding was based on the "long standing limitation" that the eighth amendment governs only punishment for criminal convictions: "Bail, fines, and punishment traditionally have been associated with the criminal process, and by subjecting the three to parallel limitations the text of the Amendment suggests an intention to limit the power of those entrusted with the criminal-law function of government.".53

This position finds hittle support in the express language of the amendment. ${ }^{54}$ Nothing in the text of the eighth amendment explicitly limits its apphication to punishments or fines resulting from criminal prosecutions; ${ }^{55}$ presuniably, an "excessive fine" is equally excessive whether based upon a criminal conviction or civil liability. The absence of an express limitation in the eighth amendment is especially notable because several provisions of both the fifth ${ }^{56}$ and sixth ${ }^{57}$ annendments explicitly apply only to criminal prosecutions. Arguably, the civil defendant needs even greater protection against excessive fines than does

51. See Jeffries, supra note 1 , at 151-58.

52. 430 U.S. 651 (1977) (5-4 decision).

53. Id. at 664 .

54. For the text of the eighth amendment, see supra note 3.

55. See Ingraham, 430 U.S. at 685 (White, J., dissenting) ("the fact that the Framers did not choose to insert the word 'criminal' into the language of the Eighth Amendment is strong evidence" that the amendment is not so limited); 1 ANNALS OF CONG. $782-83$ (J. Gales ed. 1789) (debate on excessive fines clause in the First Congress followed the debate on the fifth amendment, at which the self-incrimination clause was restricted to "criminal cases"); Jeffries, supra note 1, at 149 ("eighth amendment speaks to the severity of punishment rather than to its characterization").

56. The fifth amendment provides in pertinent part: "No person shall be held to answer for a capital, or otherwise infamous crime, unless on a presentment or indictment of a Grand Jury ... ; nor shall any person be subject for the same offence to be twice put in jeopardy of life or limb; nor shall be compelled in any criminal case to be a witness against himself, nor be deprived of life, liberty, or property, without due process of law ...." U.S. CoNST. amend. v.

57. The sixth amendment provides in pertinent part: "In all criminal prosecutions, the accused shall enjoy the right to a speedy and public trial, by an impartial jury ...; to be confronted with the witnesses against him; to have compulsory process for obtaining witnesses in his favor, and to have the Assistance of Counsel for his defence." U.S. CONST. amend. VI. 
the criminal defendant, precisely because there are fewer constitutional protections available in civil actions. ${ }^{58}$

Nor do the historical roots of the excessive fines clause support the formal approach. The language of that clause can be traced to the Magna Carta's limitation of excessive "amercements." 59 Professor Jeffries identifies amercements as ad hoc fines levied for a wide range of offenses, some of which would now be criminal, and some of which would be civil ${ }^{60}$

Strict adherence to the formal approach would clearly preclude application of the excessive fines clause to punitive damages or to any other fines imposed in civil proceedings. ${ }^{61}$ The Ingraham Court recognized, however, that the distinction between criminal and civil is not always so clear: 'Some punishments, though not labeled 'criminal' by the State, may be sufficiently analogous to criminal punishments in the circumstances in which they are administered to justify application of the Eighth Amendment." 62 Indeed, the Court has acknowledged in the past that "penalties" can be assessed in civil actions as well as criminal cases. ${ }^{63}$ Unfortunately, the Ingraham majority provided no guidelines for determining where to draw the line between criminal and civil punishments.

The functional approach to the eighth amendment attempts to define such guidelines. As the dissenting justices in Ingraham stated, under the functional approach, "[t]he relevant inquiry is not whether the offense for which a punishment is inflicted has been labeled as criminal, but whether the purpose of the deprivation is among those ordinarily associated with punishment, such as retribution, rehabilitation, or deterrence." ${ }^{64}$ Such an approach is supported by the Court's previous eighth amendment opinions.

58. See infra note 76, discussing the argument that many, if not all, protections provided by the fifth and sixth amendments should be required in actions involving possible imposition of punitive damages.

59. See supra note 46.

60. See Jeffries, supra note 1, at 154-55 \& n.65; Massey, supra note 46, at 1258-63; see also supra note 6.

61. See, e.g., Paimer v. A.H. Robins Co., 684 P.2d 187, 217 (Colo. 1984) (eighth amendment "has no application to a civil proceeding involving a punitive damages claim").

62. Ingraham, 430 U.S. at 669 n.37 (citing In re Gault, 387 U.S. 1 (1967)). The "formal" approach was rejected in favor of the "functional" in Gault, where the fifth amendment privilege against self-incrimination was held to apply to juvenile eourt proceedings, even though such actions were technically "civil" and not "criminal," and despite the provision's explicit limitation to "criminal cases." 387 U.S. at 49 . The eighth amendment has no such explicit limitation. See supra note 3; supra note 55 and accompanying text.

63. See, e.g., United States v. Ward, 448 U.S. 242, $248-51$ (1980) (\$500 "civil penalty" for violation of Federal Water Pollution Control Act); Helvering v. Mitchell, 303 U.S. 391,399 (1938) (50\% penalty for tax fraud).

64. 430 U.S. at 686-87 (White, J., dissenting). 
In Trop v. Dulles, ${ }^{65}$ the government argued that its authority to expatriate a soldier convicted of desertion was not circumscribed by constitutional limitations on punishment because the statute in question "technically [was] not a penal law."66 The Court rejected that argument, insisting that " $[t]$ he inquiry must be directed to substance" and not niere "form." 67 Chief Justice Warren reviewed the Court's prior attempts to determine whether or not a given law was sufficiently "penal" to require application of constitutional protections, ${ }^{68}$ and concluded that the key factor had been the "purpose" of the law:

If the statute imposes a disability for the purposes of punishment-that is, to reprimand the wrongdoer, to deter others, etc.-it has been considered penal. But a statute has been considered nonpenal if it imposes a disability, not to punish, but to accomplish some other legitimate governmental purpose. ${ }^{69}$

Finding that the clear purpose of "taking away citizenship from a convicted deserter is simply to punish him," the plurality subjected the statute to eighth amendment scrutiny and held it to constitute cruel and unusual punishment. ${ }^{70}$

In Kennedy v. Mendoza-Martinez, ${ }^{71}$ the Court, considering a parallel section of the same statute, ${ }^{72}$ identified seven functional criteria that, in the absence of "conclusive evidence" of legislative intent, niust be

65. 356 U.S. 86 (1958).

66. Id. at 94. The challenged statute was section $401(\mathrm{~g})$ of the Nationality Act of 1940 , codified at 8 U.S.C. $\S 1481(\mathrm{a})(8)$ (repealed 1978).

67. Trop, 356 U.S. at 95 (plurality opinion); see also id. at 94 ("How simple would be the tasks of constitutional adjudication and of law generally if specific problems could be solved by inspection of the labels pasted on them!"); United States v. Chouteau, 102 U.S. 603, 611 (1881) ("The term 'penalty' involves the idea of punishment, and its character is not changed by the mode in which it is inflicted, whether by a civil action or a criminal prosecution.").

68. Trop, 356 U.S. at $95-96$ (footnotes omitted). The Chief Justice did not limit his revierv to cases involving the eighth amendment, but drew on several constitutional provisions that "apply only to statutes imposing penalties." Id.

69. Id. at 96. For example, a "nonpenal" purpose of a law depriving a bank robber of his right to vote would be to "designate a reasonable ground of eligibility for voting." Id. at 96-97; see also United States v. Ward, 448 U.S. 242, 253 (1980) (criminal "procedural guarantees" not applicable where remedial purposes of toxic waste cleanup and pollution agency administration rendered $\$ 500$ fine a civil, rather than criminal, penalty); Massachusetts Bonding Co. v. United States, 352 U.S. 128,129 (1956) (damages measured by defendant's culpability are punitive; damages measured by plaintiff's loss are compensatory).

70. Trop, 356 U.S. at 97 . In his concurrence, Justice Brennan did not rely on the eighth amendment but argued that no "requisite rational relation" existed between the sanction and the governmental interests it was asserted to serve. Id. at 114. Justice Frankfurter's dissent applied a similar analysis but reached a contrary conclusion, finding that the statute was not penal, but an exercise of the war power. Id. at 125.

71. 372 U.S. 144 (1963).

72. The Court considered The Nationality Act of $1940, \S 401(j)$ and its successor provision in the Immigration and Nationality Act of 1952, § 349(a)(10), codified at 8 U.S.C. $\S 1481$ (a)(10) (repealed 1976). The Court framed the issues in terms of the fifth and sixth amendments rather than the eighth, but the analysis mirrored that in Trop v. Dulles. 
assessed to determine whether a particular sanction is a "punishment." These criteria were:

[w] hether the sanction involves an affirmative disability or restraint, whether it has historically been regarded as a punishment, whether it comes into play only on a finding of scienter, whether its operation will promote the traditional aims of punishment-retribution and deterrence, whether the behavior to which it applies is already a crime, whether an alternative purpose to which it may rationally be connected is assignable for it, and whether it appears excessive in relation to the alternative purpose assigned. ${ }^{73}$

In Mendoza-Martinez, however, the Court found "a detailed examination" of the seven factors unnecessary because the "objective manifestations of congressional purpose indicate[d] conclusively" the punitive nature of the sanction. ${ }^{74}$

The Court recognized the seven factors identified in MendozaMartinez as "helpful" in United States v. Ward, ${ }^{75}$ where it held that a $\$ 500$ penalty for violating of the Federal Water Pollution Control Act was not sufficiently penal to warrant application of the "procedural guarantees normally associated with criminal prosecutions." 76 The Court emphasized the "Inanifest intention [of Congress] to establish a civil, remedial mechanism,"77 noting that the money from such fines was used to help finance toxic cleanup as well as "to defray the costs of administer-

73. Mendoza-Martinez, 372 U.S. at 168-69 (footnotes omitted).

74. Id. at 169. As in Trop v. Dulles, the dissenting Justices applied a similar analysis but reached the opposite conclusion. See id. at 208 (Stewart, J., dissenting) ("The question of whether or not a statute is punitive ultimately depends on whether the disability it imposes is for the purpose of vengeance or deterrence, or whether the disability is but an incident to some broader regulatory objective."). Justice Stewart found the punitive nature of this sanction "far overbalanced" by the government's interest in preserving "wartime morale." Id. at 209.

75. 448 U.S. 242,249 (1980).

76. Id. at 253. The Court has never clearly differentiated between the analysis used to apply the eighth amendment and that used for other constitutional provisions relating to punitive sanctions. In Ward, the Court discussed the application of the self-incrimination clause to cases where the "other procedural guarantees" might not apply, but did not compare the relative scope of the eighth amendment. Id. at 253-54. In Ingraham v. Wright, the majority suggested that eighth amendment scrntiny is appropriate only "after the State has complied with the constitutional guarantees" provided by the preceding amendments. 430 U.S. $651,671 \mathrm{n} .40$ (1977).

The precise scope of the guarantees provided by the fourth, fifth, and sixth amendments is unclear, and it is likely to remain so if the Court continues to evaluate the penal nature of particular laws. Several authors, relying on the Mendoza-Martinez criteria, have argued that the penal nature of punitive damages renders such actions "quasi-criminal" and justifies application of the full panoply of procedural protections accorded criminal defendants. For a particularly thorough exposition of this argument, see Wheeler, supra note 29. See also Grass, supra note 29. It is beyond the scope of this Comment to evaluate all the ramifications of this position. Rather, the issue here is the independent application of the excessive fines clause to punitive awards. In order to focus on the severity of the punishment imposed, therefore, I assume throughout that any procedural safeguards required by due process have been observed.

77. Ward, 448 U.S. at 249. 
ing the Act." 78 The existence of this remedial purpose stands in contrast to the Court's finding in Trop v. Dulles that denationalization served "no other legitimate purpose" besides punishment. ${ }^{79}$

Outside the constitutional context, the functional approach's distinction between punitive and remedial purposes plays a similar role in distinguishing between fines imposed for criminal and civil contempt. As the Court explained in United States v. United Mine Workers, ${ }^{80}$ "[s]entences for criminal contempt are punitive in their nature . . . [while] civil contenipt [sanctions] may ... be employed ... to coerce the defendant into compliance with the court's order, and to conipensate the complainant for losses sustanied." 11 Indeed, the United Mine Workers Court held that a fine that was excessive as a sanction for criminal contempt was valid as a coercive conditional fine for civil contempt. ${ }^{82}$

The preceding review of cases demonstrates that despite the Court's narrow reading of the cruel and unusual punishments clause in Ingraham, the Court has a strong tradition of functionally analyzing the applicability of many provisions of the Bill of Rights, including the eighth amendment. Because Ingraham's formal approach is arbitrary and inflexible im nature, it should be rejected or limited to the narrow context of public schools and closely analogous situations. ${ }^{83}$ As Chief Justice Warren argued in Trop v. Dulles:

A statute providing that "a person shall lose his liberty by committing bank robbery," though in form a regulation of liberty, would nonetheless be penal. Nor would its penal effect be altered by labeling it a regulation of banks or by arguing that there is a rational connection between safeguarding banks and imprisoning bank robbers. ${ }^{84}$

The applicability of the eighth amendment in general, and the excessive fines clause in particular, should be governed, not by a sanction's formal label, but by a functional analysis of its purpose and effect.

78. Id. at 246; see also Hindt v. State, 421 A.2d 1325, 1333 (Del. 1980) ("primary objective" of fines under state Water and Air Resources Act is not punishment, but "pollution clean-up").

79. 356 U.S. 86,97 (1958).

80. 330 U.S. 258 (1947).

81. Id. at 302-04.

82. Id. at 305 . The defendant can avoid imposition of the conditional fine by purging the civil contempt and obeying the court's order.

83. Even on its own facts, the reasoning of Ingraham is hardly compelling. As the dissent observes:

The issue in this case is whether spankings inflicted on public school children for breaking school rules is "punishment," not whether such punishment is "cruel and unusual." If the Eighth Amendment does not bar moderate spanking in public schools, it is because moderate spanking is not "cruel and unusual," not because it is not "punishment" as the majority suggests.

430 U.S. at 685 n.1 (White, J., dissenting).

84. 356 U.S. at 95. 


\section{Classifying Punitive Damages as "Fines"}

Given this functional approach to the excessive fines clause, it remains to be assessed whether punitive damages are sufficiently "penal" in nature to constitute "fines" within the meaning of the eighth amendment. Using as a rough guide the Mendoza-Martinez criteria for determining whether a sanction is penal, ${ }^{85}$ this section argues that such awards are the functional equivalent of fines.

The Supreme Court has defined punitive damages as "private fines levied by civil juries to punish reprehensible conduct and to deter its future occurrence." 86 As Professor Jeffries observes, such awards "inflict monetary penalties on the basis of particularized assessments of fault."87 By definition, then, punitive damage awards satisfy several MendozaMartinez criteria: they are "affirmative disabilities" whose primary purposes "promote the aims of punishment-retribution and deterrence." 88 Furthermore, such awards have "historically been regarded . . . as punishment."89

Two other, related Mendoza-Martinez criteria focus on possible alternative governmental purposes for sanctions. For truly punitive damages, however, there is no other interest served by imposing such sanctions apart fron punishing the wrongdoer..$^{90}$ Indeed, in some respects, private fines (separate from compensation) are more likely to serve "punitive ends" than public fines, since the government is more likely to use public funds for "remedial" purposes. ${ }^{91}$

The remaining Mendoza-Martinez criteria-whether the sanction requires a finding of defendant's scienter and whether the behavior sanctioned is already crininal-are satisfied not so much by the inherent nature of punitive daniage awards, but by the way they are imposed in practice. While the standards for imposing punitive damages vary by jurisdiction, liability for such awards generally does turn on some sort of scienter requirement, usually malicious intent or reckless indifference to

85. See supra text accompanying note 73 .

86. Gertz v. Robert Welch, Inc., 418 U.S. 323, 350 (1974).

87. Jeffries, supra note 1, at 148; see also Wheeler, supra note 29, at 349 (Mendoza-Martinez criteria justify application of "constitutional criminal procedural safeguards" to punitive actions); Note, supra note 33, at 1719-24 (same conclusion, focusing on application of excessive fines clause).

88. Kennedy v. Mendoza-Martinez, 372 U.S. 144, 168-69 (1963).

89. Id.; see supra note 6 and accompanying text. Punitive awards are related to the "amercements" imposed in carly Norman England for "a very wide range of delicts and offenses." Jeffries, supra note 1, at 155; see also Massey, supra note 46, at 1258-69.

90. As stated earlier, supra note 12 and accompanying text, the scope of this Comment does not include cases in which "punitive" damages serve compensatory ends.

91. See supra note 78 and accompanying text. Proposals for the creation of "victim's funds" from punitive damage awards in product liability actions, besides reducing the "windfall" to individual plaintiffs, would also guarantee compensation for other victims of the same defective product and reduce the need for further litigation. 
the rights and safety of others. ${ }^{92}$ Moreover, even where the sanctioned behavior is not already criminal, it is arguable that the very availability of punitive damages reflects a judicial or legislative policy judgment that the government's interest in preventing such conduct warrants criminal-like sanctions. On the other hand, especially where a statute is involved, it may be argued that the legislature specifically authorized puritive damages so as not to make the conduct criminal. This view calls into question the relevance of the conduct's criminality.

The deeper question underlying this debate is whether the civil/ criminal distinction should matter. The primary difference between punitive damages and other fines is, of course, that payment is made to a private plaintiff rather than to the state. Nevertheless, as Professor Wheeler puts it, "[t]he fact that an action authorized solely for the purpose of promoting the sovereign's penal interest is brought by a private citizen does not significantly alter the nature or purpose of the action or the risk of injustice that the action entails."93 Consider, for example, the federal antiracketeering statute (RICO), ${ }^{94}$ which provides both criminal and civil penalties. ${ }^{95}$ Section 1963 authorizes forfeiture to the government of properties and interests acquired in violation of RICO. As a criminal penalty, such a sanction is unquestionably subject to review under the excessive fines clause. ${ }^{96}$ Yet Congress presumably cannot avoid constitutional scrutimy simply by labeling the forfeiture a "civil remedy" and awarding the entire proceeds to an individual plaintiff. ${ }^{97}$

Finally, though this discussion has employed the Mendoza-Martinez criteria to analyze punitive damages, the penal nature of the sanction should be self-evident to a court. No "detailed examination" is necessary to establish that punitive damages, like the sanctions imposed in Trop $v$. Dulles $^{98}$ and Mendoza-Martinez, ${ }^{99}$ are indeed a form of punishment. As monetary penalties, they should be subject to the constitutional limitation on excessive fines. ${ }^{100}$

92. See supra note 13 and accompanying text.

93. Wheeler, supra note 29, at 348. Professor Jeffries also rejects the argument that the excessive fines clause should not apply where the fine goes to a private plaintiff, arguing that "the eighth amendment was plainly designed to forbid excessive punishment, not government selfenrichment." Jeffries, supra note 1, at 148 \& n.37.

94. 18 U.S.C. $\S \S 1961-1968$ (1982).

95. Id. $\S$ 1963-1964.

96. Indeed, the Ninth Circuit has held that forfeiture of an entire enterprise for relatively minor violations might constitute an excessive fine. United States v. Busher, 817 F.2d 1409 (9th Cir. 1987).

97. See United States v. United States Coin \& Currency, 401 U.S. 715, 718 (1971) (for fifth amendment purposes, no relevant difference between civil "forfeiture" and "criminal fine"); see also supra notes $67 \& 84$ and accompanying text.

98. 356 U.S. 86 (1958); see supra text accompanying note 70.

99. 372 U.S. 144 (1963); see supra text accompanying note 74.

100. It could be argued that the protection of the excessive fines clause is limited to individuals 


\section{III}

\section{The Proper Measure of Excessiveness: PROPORTIONALITY}

That punitive damage awards should be subjected to eighth amendment scrutiny does not mean that all such awards are unconstitutional. Rather, it means simply that punitive damages, along with other fines and punishments, may not be "excessive."101 In determining excessiveness, what standards should courts apply? When does a particular punitive award violate the constitutional proscription? As Part II noted, there are no cases providing an authoritative construction of the excessive fines clause. ${ }^{102}$ Cases interpreting the cruel and unusual punishments clause provide the closest analogies. ${ }^{103}$ These cases establish that the fundamental principle underlying the eighth amendment is proportionality-the notion that punishments should not be "greatly disproportioned to the offenses charged."104

and does not extend to corporations. While it is true that some provisions of the Bill of Rights have been identified as "purely personal" and therefore unavailable to corporations, see First Nat'l Bank of Boston v. Bellotti, 435 U.S. 765, 779 n.14 (1978) (citing California Bankers Ass'n v. Shultz, 416 U.S. 21, 65-67 (1974) (fourth amendment right of privacy); Wilson v. United States, 221 U.S. 361, 382-86 (1911) (privilege against self-incrimination)), it is clear that corporations are generally protected by the fourteenth amendment's guarantees of due process and equal protection, Bellotii, 435 U.S. at 778 n. 14; id. at 780 n.15 (citing Santa Clara County v. Southern Pac. R.R., 118 U.S. 394 (1886) (corporations are "persons" for purposes of the fourteenth amendment)). Whether a particular provision protects corporations "depends on the [provision's] nature, history, and purpose." Bellotit, 435 U.S. at 779 n.14. Since major corporations are much more likely than individuals to incur massive fines or punitive damage awards that could implicate the excessive fines clause, it would be hollow formalism to apply the provision to the states but not extend its protection to corporations. Moreover, the same factors that justify imposing criminal sanctions on corporations for the conduct of their agents, see Elkins, Corporations and the Criminal Law: An Uneasy Alliance, $65 \mathrm{Kx}$. L.J. 73 (1976), justify extending to them the constitutional protections accorded to individual criminal defendants.

101. Justice Brandeis described the distinction between excessive and just punishment as the "difference between unrestrained power and that which is exercised under the spirit of constitutional limitations formed to establish justice." United States ex rel. Milwaukee Social Democratic Publishing Co. v. Burleson, 255 U.S. 407, 435 (1921) (Brandeis, J., dissenting) (quoting Weems v. United States, 217 U.S. 349, 381 (1910)).

102. See supra notes $39-40$ and accompanying text. The Court in United States v. United Mine Workers, 330 U.S. 258 (1947), found a $\$ 3.5$ million fine for criminal contempt excessive, but provided little guidance as to the scope of the proscription of excessive fines except to note that a court must consider the defendant's financial resources and the consequent seriousness of the penalty imposed. See supra notes 80-82 and accompanying text; see also infra note 128 and accompanying text.

103. See, e.g., Solem v. Helm, 463 U.S. 277 (1983); Gregg v. Georgia, 428 U.S. 153 (1976); Weems v. United States, 217 U.S. 349 (1910).

104. Solem, 463 U.S. at 286 n.11 (quoting O'Neil v. Vermont, 144 U.S. 323, 339-40 (1892) (Field, J., dissenting)). 


\section{A. The Principle of Proportionality}

The majority opinion in Solem v. Helm ${ }^{105}$ discusses in detail the doctrine of proportionality and its role in eiglith amendment jurisprudence. In Solem, the Court affirmed the Eighth Circuit's granting of a writ of habeas corpus, vacating a life sentence imposed under South Dakota's recidivist statute for passing a $\$ 100$ check on a closed account. ${ }^{106}$ Finding the principle of proportionality of sentencing to be "deeply rooted ... in common-law jurisprudence," 107 the Court held that "a crininal sentence inust be proportionate to the crime for which the defendant has been convicted." 108

Solem was the first case in which the Supreme Court unequivocally acknowledged the apphicability of the proportionality principle to a prison sentence; ${ }^{109}$ it previously had been applied primarily in capital punishment cases. ${ }^{110}$ But while the apphication of proportionality review to prison sentences has been highly controversial, ${ }^{111}$ there is little dispute

105. 463 U.S. 277 (1983).

106. Id. at 281-84.

107. Id. at 284. The Court observed that the eighth amendment represents the framers' adoption of the "English principle of proportionality." Id. at 285-86 \& n.10; see also supra note 46.

108. 463 U.S. at 290.

109. The proportionality principle was recognized as central to the eighth amendment in Weems v. United States, 217 U.S. 349 (1910), reversing a sentence (cadena temporal) imposed by the colonial government of the Philippine Islands. The cadena temporal included several penalties in addition to the prison term. Id. at 381 .

The Court reversed a minimum 90-day prison sentence following a conviction for narcotics addiction in Robinson v. California, 370 U.S. 660 (1962). The punishment was struck down as crnel and unusual on the ground that the state could not make it a criminal offense to be inflicted with the disease of narcotics addiction. "Even one day in prison would be a crnel and unusual punishment for the 'crime' of having a common cold." Id. at 667.

110. See, e.g., Coker v. Georgia, 433 U.S. 584, 601 (1977) (Powell, J., concurring) (rejecting the death penalty as "a disproportionate punishment for the crime of raping an adult woman"); Gregg v. Georgia, 428 U.S. 153, 187-88 (1976) (Stewart, J., plurality opinion) (death is not "invariably disproportionate to the crime [of murder]," as long as the risk of arbitrary or capricious sentencing is minimized through appropriate safeguards); Furman v. Georgia, 408 U.S. 238, 279 (1972) (Brennan, J., concurring) ("If there is a significantly less severe punishment adequate to achieve the purposes for which the punishment is inflicted ... the punishment inflicted is unnecessary and therefore excessive.") (citations omitted).

111. Prior to Solem, the Court had been very reluctant to consider challenges to prison sentences based on the claim that the penalty was disproportionate to the crime. In Rummel v. Estelle, 445 U.S. 263 (1980), the Court rejected a challenge to the Texas recidivist statute very similar to the challenge upheld in Solem. The Rummel Court distinguished Weems as limited to its "extreme facts," id. at 273 , and suggested that "for crimes concededly . . . punishable by significant terms of imprisonment ... the length of the sentence actually imposed is purely a matter of legislative prerogative." Id. at 274. Two years later, the Court upheld a sentence of 40 years imprisonment for possession and distribution of nine ounces of marihuana, citing Rummel as effectively limiting any challenge based on proportionality. Hutto v. Davis, 454 U.S. 370, 374-75 (1982).

The majority in Solem, over a scathing dissent by Chief Justice Burger, criticized Rummel for not providing any guidelines for determining when an eighth amendment violation has occurred, distinguished it on the basis of the availability of "reasonably early parole," 463 U.S. at 303 n.32, 
that the principle applies to the excessive fines clause. Both the majority and the dissent in Solem equate "excessive" with "disproportionate."112 Moreover, the very roots of the proportionality principle are found in the Magna Carta's prohibition of excessive fines: "A freeman shall not be amerced for a small fault, but after the manner of the fault; and for a great crime according to the heinousness of it." 113 It is difficult to imagine, apart from a wholly arbitrary "ceiling" figure, how a fine could ever be found "excessive" without some analysis of the relationship between the penalty and the offense for which it is imposed. ${ }^{114}$

\section{B. Guidelines for Proportionality Review}

Solem did more than identify proportionality as a governing principle. Drawing on the entire body of eighth amendment jurisprudence, the Court provided gnidelines for determining when a particular punishment is disproportionate to the offense for which it is imposed. Reviewing courts are to evaluate three objective factors: "(i) the gravity of the offense and the harshness of the penalty; (ii) the sentences imposed on other criminals in the same jurisdiction; and (iii) the sentences imposed for commission of the same crime in other jurisdictions."115 The first factor requires a balancing of two elements in the case at hand. The second and third factors involve a comparison of the balance struck in the immediate case with similar balances struck in analogous situations.

Practical application of these factors, as the Court explicitly recognized, requires a judgment as to the relative gravity of the offense. The

and rejected as "meritless" the argument ("recognized," but not "adopted" in Rummel) that the length of a sentence is not subject to judicial review. Id. at $288 \mathrm{n} .14$.

112. See Solem, 463 U.S. at 289 (majority opinion); id. at 313 n.6 (Burger, C.J., dissenting). The dissent argued that "cruel and unusual" refers only to the mode of punishment and not to its excessive length or severity. This argument implies that only if the eighth amendment expressly prohibited "excessive" punishment as well as "excessive" fines and bail would some type of proportionality review be required for all forms of punishment.

113. Magna Carta, ch. 20, quoted in Solem, 463 U.S. at 284 n. 10; see also supra notes 6 \& 46 and accompanying text. Professor Massey traces the proportionality principle to the lex talionis, fundamental to ancient Hebrew and Greek notions of justice. Massey, supra note 46, at 1240.

114. The Ninth Circuit has cited Solem as mandating proportionality rcview of mandatory forfeiture of property under the federal antiracketeering statute. United States v. Busher, 817 F.2d 1409, 1415 (9th Cir. 1987).

Prior to Solem, state courts often applied a proportionality test when reviewing fines challenged as unconstitutionally excessive. See, e.g., Walsh v. Gurman, 132 Conn. 58, 64, 42 A.2d 362, 365 ("amount awarded [as treble damages under Federal Price Control Act] is not so disproportionate to the offense committed as to be [unconstitutional]"), cert. denied, 326 U.S. 719 (1945); Traylor v. State, 458 A.2d 1170, 1178 (Del. 1983) (\$75,000 fine for drug trafficking was "harsh, but not so harsh as to be disproportionate to [the] offense"); State v. Trailer Serv., Inc., 61 Wis. 2d 400, 409, 212 N.W.2d 683, 689 (1973) (upholding graduated fines for violations of truck weight limits: "For a fine to be ... excessive, it must be so disproportionate to the offense as to shock public sentiment ....").

115. Solem v. Helm, 463 U.S. 277, 292 (1983). 
Court viewed this judgment as one that courts and legislatures have traditionally made, and offered several "accepted principles" on which they draw. Thus, such a judgment is made "in light of the harm caused or threatened to the victim or society, and the culpability of the offender."116 In measuring the "harm" element, courts may consider such variables as the degree of violence involved (whether actual or threatened); the "absolute magnitude of the crime" (such as the difference between grand theft and petty theft); the relationship between "greater" crimes and "lesser included offenses" (e.g., assault with intent to kill v. simple assault); and the distinction between attempted and completed crimes. ${ }^{117}$ "Culpability" can be assessed in the traditional terms of motive and intent. ${ }^{118}$

The Solem Court also considered the coinpetence of courts to compare different sentences. Acknowledging that the easiest distinction is between capital and noncapital pumshment, the Court characterized the comparison of prison sentences as "not so much . . . ordering [as] linedrawing," not unlike the line drawing required in other contexts. ${ }^{119}$ In support of its holding that sentencing comparisons with other jurisdictions are a proper means of "deciding where lines between sentences should be drawn," 120 the Court cited Baldwin v. New York, ${ }^{121}$ where it held that a jury trial was constitutionally mandated for any offense punishable by imprisonment of more than six months. The six-month line was recognized, in part, because of the "near-uniform judginent of the Nation."122

Solem also noted that courts should accord substantial deference to legislative determinations of both the gravity of particular offenses and the penalties necessary to punish and deter offenders. ${ }^{123}$ Appellate

116. Id.; see also Gregg v. Georgia, 428 U.S. 153, 189 (1976) (plurality opinion) ("We have long recognized that "[f]or the determination of sentences, justice generally requires . . . that there be taken into account the circumstances of the offense together with the character and propensities of the offender." ") (quoting Pennsylvania ex rel. Sullivan v. Ashe, 302 U.S. 51, 55 (1937)).

117. Solem, 463 U.S. at 293.

118. Id. at 293-94; see also Enmund v. Florida, 458 U.S. 782, 798 (1982) (acknowledging fundamental principle that "causing harm intentionally must be punished more severely than causing the same harm unintentionally") (quoting H. HART, PUNISHMENT AND RESPONSIBILITY 162 (1968)).

119. 463 U.S. at 294. The Court likens the process to the line drawing required by the speedy trial and jury trial provisions of the sixth amendment. Id. at 294-95.

120. Id. at 295 .

121. 399 U.S. 66 (1970).

122. Solem, 463 U.S. at 295 (quoting Baldwin, 399 U.S. at 72). At the time Baldwin was decided, only New York City did not require a jury trial for offenses punishable by more than six months' imprisonment. Id.

123. 463 U.S. at 290; see also Gregg, 428 U.S. at 176 ("The deference we owe to the decisions of the state legislatures under our federal system ... is enhanced where the specification of punishments is concerned, for 'these are peculiarly questions of legislative policy." ") (citations omitted) (quoting Gore v. United States, 357 U.S. 386, 393 (1958)). 
courts similarly should not lightly interfere with the discretion exercised by sentencing courts in applying statutory penalties to particular situations; the Court did not envision "a general rule of appellate review of sentences."124 Nevertheless, the eighth amendment requires that sentencing be done with reference to the rights of defendants as well as to the interests of the state: "No penalty is per se constitutional."125 Thus, courts should show less deference to penalties imposed without, or in abrogation of, legislative scrutiny of the relative gravity of offenses and the consequent harshness of penalties warranted. The judge or jury that imposes punishment must have adequate guidelines for assessing appropriate penalties for particular offenses. ${ }^{126}$

\section{The Principle of Proportionality Applied to Fines}

The Solem criteria for assessing the proportionality of sentences are applicable to all forms of punishment. They are as appropriate in the context of fines as in that of prison sentences. ${ }^{127}$ The distinctions the Court draws between grand theft and petty theft, and between negligence and intentional conduct, have obvious parallels in the types of offenses for which fines (or punitive damages) are imposed. The goal in both contexts is a relatively objective ranking of offenses, from those deserving fairly minor punishment to those requiring more extreme sanctions.

The Supreme Court's analysis of the standards applied in assessing fines for criminal contempt illustrates the similarity of the Court's approaches in the two contexts. Thus, in weighing the gravity of the offense for both prison sentences and fines, the primary focus is on the "harm caused or threatened . . . and the culpability of the offender."128

[T] he trial judge may properly take into consideration the extent of the willful and deliberate defiance of the court's order, the seriousness of the consequences of the contumacious behavior, the necessity of effectively terminating the defendant's defiance as required by the public interest, and the importance of deterring such acts in the future. ${ }^{129}$

124. Solem, 463 U.S. at 290 n.16.

125. Id. at 290 (citing Robinson v. California, 370 U.S. 660, 667 (1962) (unconstitutional to punish for being addicted to narcotics)).

126. The importance of a "carefully drafted statute that ensures that the sentencing authority is given adequate information and guidance" was recognized as a check on the "arbitrary or capricious" imposition of penalties in Gregg, 428 U.S. at 195 (plurality opinion).

127. For punishment imposed in a nominally civil action (such as punitive damages, or a substantial fine for violating pollution controls), it may be necessary to substitute the more generic word "offense" for the word "crime."

128. Solem, 463 U.S. at 292.

129. United States v. United Mine Workers, 330 U.S. 258, 303 (1947). Lower courts have used similar standards for reviewing fines challenged as unconstitutionally excessive. The Wisconsin Supreme Court, for example, has declared that "consideration should be given to the object designed to be accomplished, to the importance and magnitude of the public interest sought to be protected, [and] to the circumstances and the nature of the act for which it is imposed." "State v. 
The requirement in Solem that the court examine the offense in relation to other offenses should similarly apply to fines, so that the fine imposed is not substantially greater than that imposed for more serious offenses. ${ }^{130}$

An important difference between fines and other forms of punishment lies in measuring the harshness of the penalty. One factor that is almost universally considered relevant to the assessment of fines is the defendant's "ability to pay." It is almost a tautology to say that it takes a larger fine to punish or deter a wealthy defendant than it does to punish or deter a poor defendant. Accordingly, most courts are required to "consider the amount of defendant's financial resources and the consequent seriousness of the burden to that particular defendant" when assessing criminal fines. ${ }^{131}$ But considering the financial status of the defendant in the assessment of fines raises issues not confronted in the context of prison sentences. ${ }^{132}$

The principle of "ability to pay" can be used to prevent unfair penalties froin being imposed on indigent defendants. For example, the New York Court of Appeals reversed a $\$ 500$ fine as excessive on the grounds that such a fine "for a common misdemeanor, levied on a man who has no money at all, is necessarily excessive when it means in reality that he must be jailed for a period far longer than the normal period for the crime." ${ }^{133}$ However, the use of wealth as a criterion for assessing fines

Trailer Serv., Inc., 61 Wis. 2d 400, 409, 212 N.W.2d 683, 689 (quoting 24B C.J.S. Criminal Law $\$ 1978$ c, at 557 (1962)). Trailer Service was quoted approvingly by the Delaware Supreme Court in Hindt v. State, 421 A.2d 1325, 1333 (Del. 1980). Both courts also referred to the relevance of the defendant's ability to pay. See infra notes $131-41$ and accompanying text.

130. See Solem, 463 U.S. at 299 (sentence excessive because defendant was treated more severely than persons who had committed far more serious offenses).

131. Mine Workers, 330 U.S. at 304. In Mine Workers, the Court reduced a criminal contempt fine of $\$ 3.5$ million to $\$ 700,000$, but did not explain whether its decision that the fine was excessive was based on the relative gravity of the offense or on the magnitude of the fine in relation to the defendant's resources. $I d$.

132. The law does not as readily consider the age of a defendant in determining the harshness of a prison sentence. Age is obviously a consideration in distinguishing adult from juvenile offenders, but the focus is on the relative culpability of a presumptively immature person, not on the relative value of years in prison. The negative effect that the prison environment may have on young inmates is also a concern. See R. Flowers, Children and Criminality: The Child As Victim' and Perpetrator 119, 178-79 (1986); J. Hanley, Criminal Justice Processes and Procedures 184 (1983).

It is at least arguable that a 20-year-old has more "ability to pay" a 20-year sentence than does a 60-year-old. Nevertheless, the Court has given no indication that age is a permissible consideration in assessing punishment. The philosophical problem of measuring the relative value of a term of years to individuals of different ages is probably not susceptible of "objective" resolution. Even more problematic is a principled distinction between age and wealth as criteria for judging the relative harshness of penalties. For the purpose of this Comment, it must suffice to say that age is generally not considered relevant for sentencing purposes, while wealth is often seen as particularly pertinent to the assessment of fines.

133. People v. Saffore, 18 N.Y.2d 101, 104, 218 N.E.2d 686, 688, 271 N.Y.S.2d 972, 975 (1966). 
also creates an extreme risk of prejudicing the judgment. ${ }^{134}$ This danger is particularly acute where (1) the defendant is extremely wealthy, and (2) the jury is apprised of the defendant's financial status before its determination of guilt or liability. ${ }^{135}$

Although the Court has not resolved the dilemma created by considering wealth in imposing financial penalties, it has confronted analogous problems in seeking to prevent "arbitrary and capricious" justice in other contexts. In Gregg v. Georgia, ${ }^{136}$ the Court observed that "[m]uch of the information that is relevant to the sentencing decision may have no relevance to the question of guilt, or may even be extremely prejudicial to a fair determination of that question." $" 137$ Rejecting the assertion that a jury can "be expected to consider evidence before it on one issue, but not another,"138 the Court approved the use of a "bifurcated procedure," during which the jury considers the questions of guilt and punishment in separate hearings. ${ }^{139}$ In addition, the Court insisted that the jury be "carefully and adequately guided in their deliberations." 140 Such measures, embodied in "a carefully drafted statute," ${ }^{141}$ can minimize the dangers posed by potentially prejudicial evidence. While the Gregg ruling was limited to death penalty sentencing, its proposals are well suited to preventing "arbitrary and capricious" findings of liability by juries based on evidence of a defendant's wealth.

The court emphasized that the trial judge imposing the fine knew that payment was impossible. Id. The Supreme Court has used equal protection principles to void prison sentences imposed on indigent defendants solely because of their inability (not mere unwillingness) to pay fines. See Tate v. Short, 401 U.S. 395, 399-40I (1971); Williams v. Illinois, 399 U.S. 235, 242-45 (1970); see also H.F. WAy, CRiminal Justice AND the AmeriCAN Constitution 453-54 (1980) (discussing Tate and Williams).

134. See Hoffman v. Brandt, 65 Cal. 2d 549, 421 P.2d 425, 55 Cal. Rptr. 417 (1966) (judgment for plaintiff reversed because of attorney's persistent references to defendant's great wealtli); Simmons v. Southern Pac. Transp. Co., 62 Cal. App. 3d 341, 359, 133 Cal. Rptr. 42, 52 (1976) (admonishments to jury insufficient to cure prejudicial effects). Consideration of the defendant's wealth is particularly controversial in the context of punitive damages. See, e.g. Bankers Life \& Casualty Co. v. Crenshaw, 483 So. 2d 254, 279 (Miss. 1985) (Hawkins, J., dissenting in part) (accusing the majority of considering "only the net worth" of the defendant), prob. juris. noted. 107 S. Ct. 1367 (1987); see also infra notes $149-60$ and accompanying text.

135. The risk of such prejudice was one important factor in the Supreme Court's holding that punitive damages are not available against municipalities under federal civil rights statutes. City of Newport v. Fact Concerts, Inc., 453 U.S. 247, 270 (1981). The Court approved consideration of personal financial resources in assessing punitive damages against individual government officials, $i d$. at 269 , although "wealth" in this context is more likely to be a mitigating factor than an exacerbating one, since few municipal officials are likely to be particularly wealthy.

136. 428 U.S. 153 (1976).

137. Id. at 190 .

138. Id. at 190 n. 40 (citing Bruton v. United States, 391 U.S. 123 (1968); Jackson v. Denno, 378 U.S. 368 (1964)).

139. Gregg, 428 U.S. at 190-92. At least two states have adopted such a procedure for the determination of punitive damages. See infra note 165 .

140. Gregg, 428 U.S. at 193.

141. Id. at 195 . 
In summary, several principles emerge from the leading cases construing the eighth amendment. By synthesizing these principles and applying them to the context of fines, one can construct a standard by which the constitutional excessiveness of a fine or punitive damage award should be deternined.

(1) Fundamental to eighth amendment jurisprudence is the principle of proportionality: The harshness of a fine must not be disproportionate to the gravity of the offense for which it is imposed.

(2) The gravity of the offense must be measured by objective criteria to the greatest extent possible. The basic elements in this measurement include the nature and extent of the harm caused or threatened to the victim or society, and the culpability of the defendant.

(3) The penalty assessed for a particular offense should be compared both with the penalties imposed for other offenses in the same jurisdiction and with the penalty imposed for the same offense in other jurisdictions. All other factors being equal, a fine that is substantially larger than either is constitutionally suspect.

(4) Legislative determinations of the gravity of particular offenses and of the penalty necessary to punish and deter offenders should be shown substantial deference, within the limits provided by the eighth amendment.

(5) While an assessment of the relative harshness of the fine may require consideration of the defendant's ability to pay, great care must be taken to ensure that the defendant's wealth does not prejudice the determination of guilt or liability.

These standards, taken together, constitute a method of evaluating the constitutional excessiveness of fines. As Part II argued for applying this excessiveness standard to punitive damage awards, it remains only to evaluate the prevailing standards for imposing punitive damages and to assess the extent to which they comply with the proposed constitutional standard.

\section{IV}

\section{A Constitutional ANalysis of the Factors Currently Used to Determine Punitive DAMAGE AWARDS}

Applying the excessive fines clause to punitive damage awards is only a first step towards conforming state practices to constitutional standards. Divergence among the states confounds an effort to evaluate uniformly the constitutional adequacy of current practices. ${ }^{142}$ While a

142. See Jeffries, supra note 1 , at $146-47$ (solving the problem of repetitive punitive awards is not feasible at the state level; a "realistic solution . . . must be national in scope"); Mallor \& Roberts, supra note 17, at 642 \& n.18 ("judges desperately want guidance" on the "standards for imposing and assessing punitive damages"). 
comprehensive state-by-state analysis is beyond the scope of this Comment, ${ }^{143}$ some general trends are discernible.

Most striking is that courts upholding punitive damage awards, and statutes enabling juries to award them, seldom tie punitive sanctions to the principle of proportionality, ${ }^{144}$ a feature that could contribute to jurisdictional uniformity. In stark contrast to criminal sanctions and most other civil penalties, punitive damage provisions are not ranked by degrees of seriousness-there are no minimum or inaximum punishments for particular offenses. ${ }^{145}$ Rather, most states simply require a threshold of fault, usually some measure of malice or recklessness, to authorize an award of punitive damages. ${ }^{146}$ The amount of the award is left to the jury's discretion, which is informed only by vague guidelines and is subject to varying degrees of judicial review. The result is a patchquilt of judgments with no apparent pattern. ${ }^{147}$

This Part focuses on representative approaches taken by two juris-

143. At least 46 states, plus the federal government, allow such awards. See supra notes 10-26 and accompanying text for an overview of current state laws governing punitive damages. Discretionary punitive damages-other than double or treble damages-arc available under a felv federal statutes. See, e.g., 18 U.S.C. $\$ 2520$ (b)(2) (Supp. IV 1986) (illegal wiretaps); 42 U.S.C. $\S 1983$ (1982) (civil rights violations). Such awards generally have not approached the staggering magnitude of state punitive awards, at least partly because of active judicial use of remittur. Sec, e.g. Rowlett v. Anheuser-Busch, Inc., 832 F.2d 194, 206-07 (1st Cir. 1987) (\$3 million punitive damages for race discrimination in employment reduced to $\$ 300,000$, equal to compensatory award).

144. The few jurisdictions invoking the principle in punitive damage cases have not established precedent for its application. The Supreme Court of Wisconsin has held that a punitive damage award imposing a penalty "disproportionate to the wrongdoing is excessive and is contrary to public policy." Wangen v. Ford Motor Co., 97 Wis. 2d 260, 303, 294 N.W.2d 437, 459 (1980). The court acknowledged the importance of judicial scrutiny of jury verdicts to prevent excessive awards, and identified several relevant factors. Id. at 302, 294 N.W.2d at 458. Although the Wangen court clearly stated the concept of proportionality and provided guidelines for its application, its holding was essentially declarative; there are no subsequent cases that use the Wangen standard.

145. Wheeler, supra note 29, at 286; Note, supra note 17, at 1165, 1169-70. Often, in fact, punitive damages are imposed for offenses for which the legislature has provided more limited penalties. See, e.g., Grimshaw v. Ford Motor Co., 119 Cal. App. 3d 757, 820, 174 Cal. Rptr. 348, 389 (1981) (punitive damages are necessary substitutes for "inadequate and ineffective" penalties available under state or federal safety regulations and criminal laws). While the federal judiciary generally should not interfere with the relationship between a state's courts and its legislative bodies, it should scrutinize such state court judgments more carefully than awards based on established legislative guidelines. See supra notes 122-25 and accompanying text. For discussions of double jeopardy questions raised by the imposition of both criminal and civil punishments for the same offense, see K. GHIARDI \& J. KIRCHER, supra note 11, § 3.02; Wheeler, supra note 29, at 326-29; Note, supra note 17 , at 1181-84.

146. See supra note 23 and accompanying text.

147. Professor Ellis, after an extensive analysis of jury instructions and standards of appellate review, has concluded that "the lack of functional criteria for determining the appropriate size of punitive damage assessments compounds the effects of uncertain standards of liability. . . As a result, there is wide variance in the magnitude of assessments, with no apparent correlation between the amounts assessed and defendants' desert." Ellis, supra note 10, at 62. Professor Ellis defines "desert" in terms of proportionality, which he posits as a fundamental principle of fairness in the imposition of punishment. Id. at 6-7. 
dictions, Mississippi and California, and on three factors often seen as relevant to the determination of the appropriate size of a punitive damage award: (1) the wealth of the defendant, (2) the culpability of the defendant's conduct, and (3) the amount of compensatory damages awarded. The discussion measures the operation of these factors in particular circumstances against the constitutional standards proposed in Part III.

\section{A. The Wealth of the Defendant}

In Bankers Life \& Casualty Co. v. Crenshaw, ${ }^{148}$ the Supreme Court of Mississippi found three factors relevant to measurmg punitive damages:

(1) Such amount as is necessary for the punishment of the wrongdoing of the defendant and deterring defendant from similar conduct in the future ...;

(2) Such amount as is reasonably necessary to make an example of the defendant so that others may be deterred from the commission of similar offenses ...; and

(3) The pecuniary ability or financial worth of the defendant. ${ }^{149}$ The Mississippi courts allow the jury virtually unlimited discretion to determine punishment; the award will be reduced only if it is found to be "arbitrary and unreasonable," or if it "evinces passion, bias and prejudice ... so as to shock the conscience."150 In upliolding the $\$ 1.6$ million punitive award, ${ }^{151}$ the Bankers Life majority ruled that "it is difficult to imagine that ... the judicial conscience could be shocked by a punitive damages assessment which is less than $1 \%$ of the financial net wortl of the defendant."152

As noted in Part III, emphasizing the defendant's wealtli creates a serious risk of prejudicing the jury's determination of liability. ${ }^{153}$ For very wealthy defendants, moreover, evidence of financial status may influence the jury to impose a much liarsher award than the offense warrants. Sucl1 a result violates the principle of proportionality. ${ }^{154}$ Other

148. 483 So. 2d 254 (Miss. 1985), prob. juris. noted, 107 S. Ct. 1367 (1987) (No. 85-1765).

149. Id. at 278 (citations omitted).

150. Id. The court explained that the "shock must be experienced by the judicial conscience, not the actual conscience of the members of this Court." Id. (citations omitted). Justice Hawkins, who wrote for the court in upholding the defendant's liability for punitive damages but dissented as to the amount of the award, found the distinction between the "judicial" conscience and the "actual" conscience incomprehensible. Id. at 282 (Hawkins, J., dissenting in part).

151. The defendant was found to have acted in bad faith in refusing to pay an accidental injury insurance claim of $\$ 20,000$. Id. at 256.

152. Id. at 279. Justice Hawkins aceused the majority of considering "only the net worth of Bankers Life." Id.

153. See supra notes $134-36$ and accompanying text.

154. See supra notes $127-29$ and accompanying text. 
than finding that the question of liability was properly presented to the jury, the Mississippi court made no pretense of applying the proportionality review mandated by the excessive fines clause. The size of the punitive award was evaluated, not by reference to the gravity of the offense, but solely in relation to the identity and financial status of the defendant. The Supreme Court should therefore reverse the judgment in Bankers Life and remand the case for reassessment of the penalty according to the principles developed in Solem. ${ }^{155}$

The underlying issue of the role of defendant's wealth in assessing punitive damages is not so easily settled. ${ }^{156}$ Beyond saying that "a penalty which would be sufficient to reform a poor man is likely to make little impression on a rich one," 157 the questions raised by consideration of the defendant's financial status are complex and controversial. ${ }^{158}$ The need to consider ability to pay is balanced, and perhaps outweighed, by the danger that a disparity in wealth between the plaintiff and defendant will prejudice the jury's verdict on fault as well as unduly influence it to award disproportionately large penalties. ${ }^{159}$ In analyzing the excessiveness of a punitive damage award, the harshness of the penalty should be kept conceptually distinct from the wrongfulness of the conduct. The defendant's wealth is relevant only to the harshness side of the proportion, not to the wrongfulness side, and the danger of jury prejudice arises when this distinction gets blurred. ${ }^{160}$

Commentators have proposed a variety of solutions to resolve the

155. The Ninth Circuit provided a concise statement of the standards to be applied on remand in United States v. Busher, 817 F.2d 1409, 1415 (9th Cir. 1987) (remanding RICO forfeiture case for determination of proportionality of punishment according to guidelines established in Solem $v$. Helm, 463 U.S. 277, 292 (1983)).

156. Most jurisdictions admit evidence of the defendant's financial status in trials for punitive damages. K. REDDEN, supra note 5, at 61 (1980).

157. Morris, Punitive Damages in Tort Cases, 44 Harv. L. Rev. 1173, 1191 (1931); see also Neal v. Farmers Ins. Exch., 21 Cal. 3d 910, 928, 582 P.2d 980, 990, 148 Cal. Rptr. 389, 399 (noting that the deterrence function "will not be served if the wealth of the defendant allows him to absorb the award with little or no discomfort").

158. See supra notes 131-36 and accompanying text.

159. Professor Morris recognized the danger of jury prejudice against wealthy defendants in 1931, when he observed that "rich men do not fare well before juries, and the more emphasis placed on their riches, the less well they fare." Morris, supra note 157, at 1191. A number of modern commentators have concluded that "using wealth as a factor in determining the size of punitive damage assessment . . . invites otherwise unguided juries to indulge any redistributive inclinations they may have [and] produces inefficient incentives." Ellis, supra note 10, at 61-62; see also Mallor \& Roberts, supra note 17, at 665 (risk of the "Robin Hood" syndrome justifies separating issues of liability and punishment, reserving the latter for the judge); Owen, supra note 1, at $45-46$ ("a jury instructed to use the 'wealth' of a multi-million or multi-billion dollar corporation as a yardstick in assessing punitive damages is almost forced to think in terms of seven . . . eight . . or even nine figures").

160. This was precisely the problem identified by Justice Hawkins in Bankers Life; he recognized that "the wealth of the defendant . . . is only relevant in determining an amount that constitutes meaningful punishment, . . . it has nothing to do with public cxample or reward to the 
dilemma posed by the need to know the defendant's ability to pay and the counterbalancing danger of jury prejudice. Most of these proposals attempt to implement the above-mentioned distinction, that is, to separate, as fully as possible within our framework of law and procedure, the gravity of the offense from the harshness of the penalty.

The traditional approach is to rely on careful jury instructions, cautioning the jurors to separate the two issues in their minds. ${ }^{161}$ Unfortunately, the ability of even the most responsible jurors to prevent knowledge of the defendant's wealth from coloring their perceptions of the underlying equities of a case is highly suspect. ${ }^{162}$ It is virtually impossible, moreover, for a reviewing court to know whether a jury has been successful in this effort. Acknowledging this difficulty in related contexts, the Supreme Court has concluded that "a jury cannot be expected to consider certain evidence before it on one issue, but not another."163 The "jury instruction" approach is thus inherently unreliable; it fails to provide real standards for assessing punitive awards. ${ }^{164}$ Where this approach constitutes the only procedural safeguard against jury prejudice, resulting awards should be subject to constitutional challenge under the excessive fines clause.

An alternative procedure is the bifurcated trial, where the jury determines liability for punitive damages before bemg allowed to hear evidence relevant to the size of the award, including evidence of the

plaintiff. ... I cannot agree with the concept the bigger they are the more we ought to zap them." 483 So. $2 \mathrm{~d}$ at 280 (Hawkins, J., dissenting in part).

161. See, e.g., Feld v. Merriam, 314 Pa. Super. 414, 461 A.2d 225 (1983) (upholding a punitive award of $\$ 2$ million against a landlord for failure to provide tenants with adequate security from criminal assaults), rev'd, 506 Pa. 383, 485 A.2d 742 (1984). The superior court in that case upheld the trial court's admission of evidence of the defendant's wealth and approved the following "caution" to the jury:

This evidence, members of the jury, of the net worth of $\$ 40$ million dollars is to be used by you as an aid or as a guide to determine the amount of damages which will serve the punishment purposes. It is not to be used by you as a method of inflaming your patience [sic], or prejudice, against this defendant because he happens to be a wealthy or prosperous person.

$314 \mathrm{~Pa}$. Super. at $439,461 \mathrm{~A} .2 \mathrm{~d}$ at 238 . The state supreme court reversed on the grounds that landlords have no general duty to protect tenants against criminal intrusions, $506 \mathrm{~Pa}$. at 390,485 A.2d at 745; that the submission of the punitive damage issue to the jury was error without evidence of evil motive or reckless indifference, id. at 396,485 A.2d at 748; and that the jury had not been properly warned that they could not consider defendant's wealth in setting compensatory damages, id. at 397,485 A.2d at 748 . The court acknowledged that a defendant's wealth is relevant to the amount of punitive damages, and while not expressly approving the jury instruction quoted above, noted that "a sufficient cautionary instruction may overcome the prejudice triggered" by such evidence. Id. \& n.6, 485 A.2d at 748 \& n.6.

162. See Owen, supra note 1 , at 20.

163. Gregg v. Georgia, 428 U.S. 153, 190 n.40 (1976) (citing Bruton v. United States, 391 U.S. 123 (1968); Jackson v. Denno, 378 U.S. 368 (1964)); see supra notes 136-41 and accompanying text.

164. See Ellis, supra note 10, at 53-54 \& nn.221-25 (surveying jury instructions on "permissible magnitude of punitive damage assessments"). 
defendant's financial status. Bifurcation has been adopted in a few states, ${ }^{165}$ and the American Bar Association has recommended its acceptance in all punitive damage suits. ${ }^{166}$ The Supreme Court has approved this approach in death penalty cases, ${ }^{167}$ so the procedure would presumably pass muster if applied to punitive damages. But while bifurcation might protect the basic judgment of fault from being prejudiced by the defendant's wealth, ${ }^{168}$ it would not resolve other problems associated with assessing punitive damages on a giant corporation or a very wealthy individual. In particular, the procedure does not at all address the danger of disproportionally large awards. Without guidelines as to what criteria of wealth to consider, ${ }^{169}$ how to measure the deterrent effect of a particular award, ${ }^{170}$ and how to gauge the proportion between the harshness of the penalty and the wrongfulness of the conduct, the jury's discretion remains virtually unbounded. ${ }^{171}$

These problems have prompted several commentators to urge removing the determination of punitive awards from the jury altogether and giving the decision to the judge. ${ }^{172}$ Professor Owen supports such a suggestion, in part because "judges would be able to call upon their experience in criminal sentencing . . . [and would] have a more sophisticated appreciation than jurors of the often far-reaching effects that punitive damages awards may have on the operations of particular corporate

165. See, e.g., Gierman v. Toman, 77 N.J. Super 18, 24-25, 185 A.2d 241, 245 (1962) (mandating bifurcated procedure in punitive damage trials); Rupert v. Sellers, 48 A.D.2d 265, 27172, 368 N.Y.S.2d 904, 912 (1975) (same, citing Gierman). A similar procedure was proposed by the defendant, and rejected by the trial court, in Feld, $314 \mathrm{~Pa}$. Super. at 438, 461 A.2d at 237; see supra note 161 .

166. See Corcoran, Section Plays Key Role in Tort Reform Debate, LiTigation News, Spring 1987, at 1, 8 (reporting on passage of tort reform proposals by ABA House of Delegates in February 1987). See generally J. McCarthy, Punitive Damages IN BaD Faith Cases $§ 4.5 B$, at 519-20 (4th ed. 1987) (discussing tactical considerations of plaintiffs and defendants in bifurcated trials).

167. Gregg, 428 U.S. at 190-91.

168. But see Barth v. B.F. Goodrich Tire Co., 265 Cal. App. 2d 228, 241, 71 Cal. Rptr. 306, 313 (1968) (admission of evidence of defendant's financial status probably did not affect judgment, since company "is universally recognized as a large and prosperous corporation").

169. See Owen, supra note 1, at 19-20 (difficult for juries to understand what "' wealth' really means in the case of a manufacturing entity").

170. See id. at 45 (most jurors ill equipped to determine effect of a given level of damages on major manufacturing enterprise); Ellis, supra note 10, at 57 (potential liability for uncertain amounts of punitive damages may lead to both under- and over-deterrence); see also R. COOTER \& T. ULEN, LAW AND ECONOMICS 388-97 (1988) (proposing economic analysis of deterrent effect of punitive damage awards as substitute for "jury's intuitions").

171. The Gregg Court similarly recognized that procedural solutions were "not alone sufficient to guarantee" that punishment would be based on appropriate criteria and stressed the importance of adequate guidance by the state. 428 U.S. at 192-93.

172. See, e.g., Mallor \& Roberts, supra note 17, at 664 ("Beyond being more aware of the public policy implications of the award of punitive damages, judges have more experience in meting out punishment."); Owen, supra note 10, at 1320 (outlining several advantages of such a proposal). Such a provision has been enacted into law in at least one state. See ConN. GEN. STAT. ANN. § 52-240b (West Supp. 1987). 
defendants." 173 While the states may not be constitutionally bound to remove the determination of punitive damage awards from the jury, such a proposal would help to reduce the risk of awards based on the "Robin Hood syndrome." 174

Resolving all the complex issues raised in this section is beyond the scope of this Comment, but the foundation for a solution has been set forth above. In assessing punitive damages, the gravity of the offense must be considered apart from the harshness of the penalty. Any system that allows the defendant's wealth to affect the assessment of the gravity of the offense or that places excessive emphasis on wealth in determining the punishnient is constitutionally suspect under the proposed standards derived from the excessive fines clause. ${ }^{175}$

\section{B. The Wrongfulness of the Defendant's Conduct}

No one disputes that the wrongfulness of the defendant's conduct is relevant to the determination of punitive damages. All jurisdictions require some degree of fault beyond simple neghigence before punitive damages are iniposed in any amount. ${ }^{176}$ Nevertheless, if the principle of proportionahity is to have any meaning in assessing the appropriate amount of punitive awards, the neasure of the conduct's culpability must go beyond identifying the existence of malice or reckless disregard; some notion of degree is required to distinguish acts justifying relatively ninor awards from those supporting much larger judgments. ${ }^{177}$ For example, a manufacturer who fails to renedy a defect that it knows will cause niajor injury to $20 \%$ of the people who use the product is more culpable than one who disregards a defect likely to cause only minor injuries to a nuuch snialler percentage of consumers. ${ }^{178}$ Though both may be guilty of reckless disregard of safety and therefore liable for punitive damages, the principle of proportionality mandates (all other factors being equal) that the more reckless manufacturer receive the greater penalty. ${ }^{179}$

173. Owen, supra note 10 , at $1320-21$.

174. The phrase is borrowed from DuBois, Punitive Damages in Personal Injury, Products Liability and Professional Malpractice Litigation: Bonanza or Disaster, 43 INS. CoUNS. J. 344, 353 (1976), cited in Mallor \& Roberts, supra note 17, at 665.

175. See supra Part III.

176. See supra note 23; see also Andor v. United Air Lines, 303 Or. 505, 517, 739 P.2d 18, 25 (1987) (airline not liable for punitive damages absent evidence of "extraordinary disregard of or highly irresponsible indifference to known or highly probable risks to others").

177. See Neal v. Farmers Ins. Exch., 21 Cal. 3d 910, 928, 582 P.2d 980, 990, 148 Cal. Rptr. 389, 399 (1978) ("the more reprehensible the act, the greater the appropriate punishment").

178. See Owen, supra note 10, at 1317 ("the more certain the manufacturer that its product was excessively hazardous, and the more dangerous the particular hazard of which it was aware, the more serious its misconduct") (footnote omitted).

179. Accordingly, Justice Hawkins urged the Bankers Life court to consider "attendant 
More controversial than the need to consider the defendant's culpability is the extent to which this factor can be determinative without regard to the actual harm caused to the plaintiff. ${ }^{180}$ Several courts and commentators have asserted that the amount of actual damages caused by the defendant has little or no bearing on the size of money judgment that would serve as the most effective admonition in a particular case. ${ }^{181}$ The gravity of the offense, according to this view, is equivalent to the reprehensibility of the underlying conduct, not the seriousness of the result. This argument rests squarely on the deterrence function of punitive damages, and focuses on "probable" or "likely" results rather than the actual consequences of defendant's behavior. Professor Morris provided the classic statement of the argument in 1931:

The probable result of a defendant's behavior is an important consideration in determining whether it is desirable to discourage such behavior in the future; the probable result is the measure of the "seriousness" of his wrong. ... For example, the grossly negligent hunter may shoot into a crowd of people and only break a ten-dollar pair of eye glasses. The admonition meted out to him should be the same as though he had killed or injured someone. ${ }^{182}$

The essential problem with this approach, however great its intuitive appeal, is that it conflicts with one of the precepts of proportionality, recognized by the Supreme Court as essential to the objective comparison of offenses. ${ }^{183}$ Professor Morris' conclusion, if followed literally, would eliminate any consideration of the "absolute magnitude" of the harm; stealing a million dollars would presumably be no more punishable than stealing a thousand dollars, so long as the mens rea were the same. ${ }^{184}$

circumstances," such as "the degree of the offense, ... whether there was malice; motive; the injury intended; public sense of justice and propriety[;]" and that defendant was a first offender. Bankers Life \& Casualty Co. v. Crenshaw, 483 So. 2d 254, 281-82 (Miss. 1985) (Hawkins, J., dissenting in part) (citations omitted), prob. juris. noted, 107 S. Ct. 1367 (1987). On the basis of these factors, Justice Hawkins would have reduced the punitive award from $\$ 1.6$ million to $\$ 750,000$. Id. at 282 . Such factors are similar to those considered important to the measurement of "culpability" in Solem v. Helm, 463 U.S. 277, 293-94 (1983); see supra notes 116-18 and accompanying text.

180. Reference to actual damages is conspicuously absent from Justice Hawkins' list of "attendant circumstances." See supra note 179.

181. See, e.g., Richards Co. v. Harrison, 262 So. 2d 258, 263 (Fla. Dist. Ct. App.), cert. denied, 268 So. 2d 165 (Fla. 1972); Ellis, supra note 10, at 58-59; Mallor \& Roberts, supra note 17, at 666; Morris, supra note 157 , at 1181 .

182. Morris, supra note 157 , at 1181 .

183. Solem, 463 U.S. at 293; see supra note 117 and accompanying text. Although the Solem majority spoke of "the harm caused or threatened," it did not treat actual harm as equivalent to threatened harm. Rather, the Court recognized that "attempts are less serious than actual completed crimes," 463 U.S. at 293 , thus emphasizing the necessity of considering results as well as risk.

184. Professor Ellis acknowledges 'the principle of 'aggravated harm,' under which the punishment prescribed by statutes and imposed by courts is often a function of the resulting harm as well as the nature of the act causing it." Ellis, supra note 10, at 58-59; see also Note, supra note 17, at 
Consider the radical implications of Professor Morris' example. If the "grossly negligent hunter" is to be punished "as though he had killed or injured someone," such punishment would presumably be appropriate even if no one was injured. The constitutional infirmity of such a suggestion in the context of criminal sanctions is readily apparent in light of the Court's holding in Coker v. Georgia ${ }^{185}$ that a punishment appropriate for murder may be unconstitutionally harsh for the crime of rape, but if the rape results in the victim's death, the more severe punishment is permissible. ${ }^{186}$

Even in the context of civil damages, the assumption underlying Professor Morris' example is flawed. All that would be required to subject the hunter to the full extent of liability is a finding that injury was "likely." But to whom is the hunter liable? The argument provides no reason, let alone criteria, to distinguish between potential plaintiffs; the person who lost the eyeglasses would presumably have no more right to punitive damages than another bystander who might have been injured but was not, and no less right than someone whose child or spouse was killed by the same recklessness.

Applied to contemporary products liability, the implications of Professor Morris' view become even more pernicious. A key difficulty in assessing the reprehensibility of a particular business practice is evaluating personal and institutional motives. ${ }^{187}$ This evaluation is particularly problematic in suits against large business enterprises whose basic motivation-the desire to maximize profits-is often viewed with considerable suspicion. ${ }^{188}$ As a result, any effort to determine the cost-benefit

1169 ("while the requisite conduct and intent should justify imposition of punishment, the extent of injury may be relevant to determine the amount").

185. 433 U.S. 584, 597 (1977).

186. Id. at 598 .

187. Professor Owen has contributed greatly to the analysis of the determination of states of mind and the nature of various misdeeds. See Owen, Civil Punishment and the Public Good, $56 \mathrm{~S}$. CAL. L. REv. 103, 105 (1982), quoted in Andor v. United Air Lines, 303 Or. 505, 512 n.8, 739 P.2d 18,23 n.8 (1987).

188. See, e.g., Feld v. Merriam, 314 Pa. Super 414, 435, 461 A.2d 225, 236 (1983) ("reckless disregard" found where landlord's "refusal to implement . . . increased security measures was the result of a conscious business decision"), rev'd, $506 \mathrm{~Pa}$. 383, 485 A.2d 742 (1984). Professor Owen has suggested that "punitive damages should be used to attack directly the profit incentive that generated the marketing misconduct." Owen, supra note 10, at 1316. He does not mean that the "profit incentive" is itself an evil; he has also noted that "the increasing number and size of [punitive damage] awards may fairly raise concern for the future stability of American industry." Owen, supra note 1 , at 6 .

In making institutional decisions regarding product safety, the comparison of costs and benefits of each alternative is a crucial step. A responsible business attempts to discover and maintain the optimal level of both safety and profits. The irresponsible, reckless company seeks only to maximize profit, while taking unacceptable risks at the expense of the public. What distinguishes the two is the reckless disregard of the extent and gravity of the risk, not the profit motive. Scc Owen, supra note 10, at 1317. The desire to "extract the profit realized" from tortious behavior is aimed at increasing 
efficiency of particular safety mechanisms can be seen as callously trading lives for profits. ${ }^{189}$ The danger of an excessively punitive response, already present in the mass tort situation, is magnified in this context.

This is not to say that punitive damages are never justified, or that some conduct is not sufficiently reprehensible to justify a substantial sanction. The point is that the assessment of the defendant's culpability should be comparative; the size of a particular award (all other factors being equal) should represent a judgment as to the relative culpability of the conduct giving rise to the liability. Comparing the actual injury to the punitive sanction provides an objective counterbalance to the inevitably subjective assessment of the "character" of the conduct. ${ }^{190}$

\section{The Amount of the Compensatory Damage Award}

The most common method of determining the appropriate amount of punitive damages is the "reasonable relationship" rule: "[E]xemplary damages should bear a reasonable relation to actual damages, even though no fixed ratio exists to determine the proper proportion."191 The

the severity of the penalty to the point at which it will deter future similar decisions by the defendant or others in like situations. Id. at 1316. The restitution of profit gained from the wrongdoing may be, in some circumstances, an appropriate measure of the remedy, but it is not an indication of how wrongful the conduct was in the first place. It is presumably possible to make large profits on the basis of responsible decisions as well as reckless ones.

189. Owen, supra note 1, at 11:

In addition to problems of comprehension, jurors have a natural sympathy for a seriously injured person that is reinforced when the defendant is a manufacturer, for many persons are hostile toward major institutions in general and "big business" in particular. Some jurors may thus be tempted to resort to simplistic explanations of the issue (such as that the defendant callously "traded lives for dollars") that comport with their preconceived notions of manufacturers' oppression of consumers.

(citations omitted). Professor Owen cites Ford's cost-benefit analysis of the Pinto's fuel system as an example of this problem. Id at 56; see Grimshaw v. Ford Motor Co., 119 Cal. App. 3d 757, 819, 174 Cal. Rptr. 348, 388 (1981) (Ford's management "exhibited a conscious and callous disregard of public safety in order to maximize corporate profits"). The appellate court in that case thus agreed that the reprehensibility of Ford's conduct justified punitive damages of \$3.5 million, the amount to which the award had been reduced by the trial court, but it did not indicate whether the conduct, though "reprehensible in the extreme," would have supported the jury's original award of $\$ 125$ million. Id.

190. This problem is not unlike the problem of jury sentencing faced in Gregg v. Georgia, 428 U.S. 153, 190-95 (1976). There, the Court recognized the problems inherent in allowing inexperienced juries to make complex sentencing decisions, and urged the development of jury instructions that refiect objective standards the state "deems particularly relevant to the sentencing decision." Id. at 192.

The Oregon legislature has established criteria for the assessment of punitive damages in products liability actions. OR. REv. STAT. $\$ 30.925$ (1983), discussed in Andor v. United Air Lines, 303 Or. 505, 512 n.8, 739 P.2d 18, 23 n.8 (1987). The statute focuses on measures of defendant's culpability, including "the likelihood of serious harm, the degree of defendant's awareness thereof, the profitability of defendant's misconduct, the duration and any concealment of the conduct, and the defendant's reaction to its discovery." Andor, 303 Or. at 512 n.8, 739 P.2d at 23 n.8.

191. Rosener v. Sears, Roebuck \& Co., 110 Cal. App. 3d 740, 751, 168 Cal. Rptr. 237, 243 (1980), appeal dismissed, 450 U.S. 1051 (1981). 
California Supreme Court has indicated that the purpose of using coinpensatory damages as a yardstick in assessing punitive damages is to apply an objective measure of harm in addition to the subjective measure of the conduct's gravity: "[E]ven an act of considerable reprehensibility will not be seen to justify a proportionally high amount of punitive damages if the actual harm suffered thereby is small." 192 Thus, the assumption underlying the reasonable relationship rule is that the amount of actual damages is a rough (but objective) measure of the amount of actual harm caused by a defendant's conduct. ${ }^{193}$

\section{Criticisms of the Reasonable Relationship Rule Answered}

The reasonable relationship rule has been subjected to extensive criticism. ${ }^{194}$ The objections to the rule fall into two broad categories, one focusing on its asserted arbitrariness, and another challenging its indifference to societal harm resulting from the defendant's conduct. ${ }^{195}$ The following discussion explores each of the leading criticisms and argues that they are either overstated or based on faulty premises.

\section{a. Arbitrariness}

The reasonable relationship rule is often criticized because it does not impose a fixed mathematical ratio between the punitive award and compensatory damages, and thus allows "enormous variations in the ratio of punitive to compensatory damages." 196 Critics contend that this flexibility in the rule's application renders it "vacuous," because it "provides no rational basis for deciding whether the size of a punitive damage

192. Neal v. Farmers Ins. Exch., 21 Cal. 3d 910, 928, 582 P.2d 980, 990, 148 Cal. Rptr. 389, 399 (1978).

193. The reasonable relationship rule is logically inapplicable to a situation where punitive damages are assessed on top of nominal damages, as in cases of libel or deprivation of constitutional rights. See, e.g., Finney v. Lockhart, 35 Cal. 2d 161, 217 P.2d 19 (1950) (\$1 compensation, \$2000 punitive damages for libel per se). Punitive damages in such cases may serve to compensate the plaintiff for the "indignity" or "outrage" connected with the nonpecuniary injury.

194. See, e.g., Ellis, supra note 10, at 58-60 (reasonable relationship principle inadequate in that actual harm is crude measure of moral egregiousness of defendant's conduct and hence of punishment deserved); Mallor \& Roberts, supra note 17, at 666-67 (rule is artificial since no specific ratio of punitive to actual damages has ever been established); Morris, supra note 157, at 1180; Comment, Punitive Damages and the Reasonable Relation Rule: A Study in Frustration of Purpose, 9 PAC. L.J. 823 (1978); Note, Egan v. Mutual of Omaha Insurance Co.: The Reasonable Relation Rule, the Tax Laws, and the Excessiveness of Punitive Damage Awards, 13 U.C. DAvis L. REV. 357, 364-66 (1980).

195. The preceding section of this Comment considered, and rejected, the argument that actual injury, to the plaintiff or to others, has no relevance to the determination of the appropriate level of punitive damages. See supra notes $180-90$ and accompanying text. Solem v. Helm established that both culpability and harm are important to the determination of the relative gravity of an offense. 463 U.S. 277 (1983).

196. Ellis, supra note 10 , at 60 . 
assessment is appropriate."197 Other commentators have defended the rule, even as an "arbitrary limit," because it serves as a "control device" to restrain the "inherent volatility" of punitive damage awards, especially in product liability suits against manufacturers. ${ }^{198}$ Furthermore, even critics of the rule often recognize its "historical antecedents and contemporary statutory parallels." 199

While it is arguable whether a fixed ratio would be workable in all situations or an undesirable restriction on the discretion of juries and courts to deal with cases on an individual basis, ${ }^{200}$ the need for quantifiable, objective measures of the gravity of harm speaks in favor of at least a "flexible" ratio. Furthermore, the choice is not, as some critics seem to suggest, between mechanical application or abandonment of the rule. The court in Neal v. Farmers Insurance Exchange, ${ }^{201}$ for example, recognized that justice is not necessarily served by mechanical application of the rule. Since the "fortuitous occurrence" of the insured's death prevented recovery for her emotional distress, and hence unduly limited the amount of her compensatory damages, the court focused on the harm that was actually inflicted rather than the amount of recoverable compensatory damages. ${ }^{202}$ Another "middle ground" alternative was proposed by the Special Committee on Punitive Damages of the ABA's Litigation Section. ${ }^{203}$ The Committee recommended a "presumption" of excessiveness where the punitive award is greater than three times the compensatory damages. This presumption would shift the burden to the plaintiff to show "special circumstances" that warrant a larger punitive award. ${ }^{204}$

197. Id.

198. Owen, supra note 1, at 48; see also Rosener v. Sears, Roebuck \& Co., 110 Cal. App. 3d 740, 753, 168 Cal. Rptr. 237, 245 (1980) ("Without the reasonable relationship instruction, the discretion of the jury becomes simply limitless."), appeal dismissed, 450 U.S. 1051 (1981).

199. Ellis, supra note 10, at 58 (citing Exodus 22:9 (double damages for trespass to goods); 15 U.S.C. $\$ 15$ (1982) (treble damages for antitrust violations)).

200. This perspective is acknowledged by Mallor \& Roberts, who nonetheless criticize the reasonable relation rule as "artificial" because of the lack of a "specific ratio." Mallor \& Roberts, supra note 17 , at 666.

201. 21 Cal. 3d 910, 582 P.2d 980, 148 Cal. Rptr. 389 (1978).

202. Id. at 929, 582 P.2d at 991,148 Cal. Rptr. at 400.

203. Punitive Damages: A Constructive Examination, 1986 A.B.A. SEc. L1TIG. REP. 6-10 to 6-12 (Report of Special Committee on Punitive Damages) [hereinafter Special Committee Report]; see Mayne, Punitive Damages Committee Completes Work, Recommends Caps on Punitive Awards. Litigation News, Winter 1987, at 3. The Committee's report was based on a statistical review of jury verdicts over several years.

204. Special Committee Report, supra note 203, at 6-11; Mayne, supra note 203, at 10. The proposal that a punitive award exceeding three times the compensatory award be presumed excessive was not included in the joint resolution adopted by the ABA House of Delegates in February 1987, but was replaced by "a more general standard, involving examining the degree of departure from typical ratios as reflected in the best empirical data." Corcoran, supra note 166, at 8 . The resolution, which incorporated many of the Special Committee's proposals, was sponsored by the 
Closely related to the argument that the reasonable relationship rule is arbitrary is the complaint that courts use the rule as a "shield" for their real reasons for limiting the size of punitive damages. ${ }^{205}$ The same claim, of course, can be made for virtually any basis of review, including the gravity of the conduct or the wealth of the defendant. The failure of courts to articulate their reasons for reaching a particular result is unique neither to the reasonable relationship rule nor to the assessment of punitive damages. ${ }^{206}$ Further, this complaint does not lead inexorably to the conclusion that the rule should be abandoned; it could just as well justify giving more substantive content to the definition of "reasonable," and requiring courts to be more explicit im explaining their decisions. ${ }^{207}$

\section{b. Indifference to Societal Harm}

The second major criticism of the reasonable relationship rule is that focusing on the plaintiff's injury ignores the harm inflicted by the defendant on others similar to plaintiff and on society as a whole. This complaint seems particularly persuasive in the context of insurance "bad faith" litigation, where the wrong to the individual plaintiff may represent but one instance of a company-wide or even industry-wide practice of tortious conduct. ${ }^{208}$ Since the pecuniary loss to each policy claimant may be too small to make litigation economically feasible, large punitive damage awards may provide the incentive necessary to protect society's interests and deter the undesirable behavior. ${ }^{209}$ Products liability litigation is similar; when a recklessly designed product causes minor injury to many people, the "actual" damages available to such potential plaintiffs may be too small to induce them to file suit. A successful suit protects

Litigation Section, the Tort and Insurance Practice Section, and the Action ("McKay") Commission to Improve the Tort Liability System. Id.

205. See, e.g., Morris, supra note 157 , at 1180 ("This test is probably more often a rationalization of results than a means of obtaining them.").

206. See, e.g., Gregg v. Georgia, 428 U.S. 153, 195 (1976).

207. See id. ("sentencing authority is required to specify the factors it relied upon in reaching its decision" in order to facilitate meaningful review of capricious judgments).

208. See, e.g., National Life \& Acc. Ins. Co. v. Miller, 484 So. 2d 329, 339 (Miss. 1985) (Hawkins, J., specially concurring) (imputing life insurer's conduct to "[t]he insurance companies"). See generally J. MCCarthy, Punitive Damages 1N BAD Faith Cases (4th ed. 1987) (comprehensive survey of cases and discussion of pretrial, trial, and posttrial procedures in bad faith cases).

209. The same justification is given for the treble damages provision of the Clayton Antitrust Act, 15 U.S.C. $\S 15$ (1982). See Brunswick Corp. v. Pueblo Bowl-O-Mat, Inc., 429 U.S. 477, 486 n. 10 (1977). Recall the very similar justification for the practice of multiple damages in 13th-century England. See supra note 6. The punitive damage award in Bankers Life was upheld on precisely these grounds; the Mississippi Supreme Court focused entirely on the need to punish and deter the challenged practice, and the desirability of rewarding plaintiff for "bringing the wrongdoer to account." Bankers Life and Casualty Co. v. Crenshaw, 483 So. 2d 254, 268-69 (1985), prob. juris. noted, $107 \mathrm{~S}$. Ct. 1367 (1987). No attempt was made to relate the punitive damage award to the actual injury incurred by the plaintiff. 
others from the offending practice or product and from similar industry decisions in the future. ${ }^{210}$

There are several responses to this argument. First, the argument does not justify disproportionate punitive awards in all cases, but only in those where such an award is likely to punish or deter conduct harmful to society as a whole. Further, as Justice Hawkins observed in his Bankers Life dissent, the interest of "rewarding plaintiff and his counsel for the service they have rendered this state in bringing this action" cannot justify multimillion dollar awards. ${ }^{211}$ Even if we make the questionable assumption that the state has no alternative options for protecting the interests of its consumers, ${ }^{212}$ the need to encourage "socially desirable" litigation might be met by providing attorneys' fees, treble damages, or minimum recoveries for particular wrongs.

Second, proponents of allowing individual plaintiffs to recover for the harm done to "society" often are not clear as to whether a plaintiff has to prove the existence of widespread harm, or whether the mere allegation or inference of an offending "practice" will suffice. If the latter, the defendant risks pumishment for wrongdoing that has not been proven-an apparent violation of due process. ${ }^{213}$ This problem is even more pronounced if the defendant is threatened with punishment for the acts of an entire industry.

Finally, and most important, the objection that the reasonable relationship rule places insufficient emphasis on societal harm fails to address the extent to which an individual plaintiff should be allowed to recover for injuries inflicted on other people. How many such awards are to be allowed? If 100 plaintiffs bring actions against a single defendant for conduct that likely injured 1000 persons, is the defendant liable to each plaintiff for the full punitive award, or should the award be divided by 10 (or 100 , or 1000) to avoid "punitive overkill"? What if, as is often the case, it is unknown how many suits have been or will be filed in response to the same practice? These problems, inherent in the application of punitive damages to mass tort litigation, have been recognized by a

210. See Wangen v. Ford Motor Co., 97 Wis. 2d 260, 289, 294 N.W.2d 437, 453 (1980); see also Schmidt v. Pine Tree Land Dev. Co., 291 Or. 462, 466, 631 P.2d 1373, 1377 (1981), quoted in Andor v. United Air Lines, 303 Or. 505, 514, 739 P.2d 18, 24 (1987).

211. 483 So. $2 \mathrm{~d}$ at 281 (Hawkins, J., dissenting as to the size of the award). Compensation for "private attorneys general" may justify payment of punitive damages to the plaintiff rather than to the state; the penalty itself, however, must be measured in terms of the gravity of the offense. See Ellis, supra note 10, at 10 (identifying "private law enforcement" as "a dependent purpose at best").

212. See National Life \& Acc. Ins. Co. v. Miller, 484 So. 2d 329, 339 (Miss. 1985) (Hawkins, J., specially concurring) (in awarding punitive damages, the "court has been called upon to redress grievances which could be avoided by proper state regulation of insurance company practices").

213. While the Court in Solem $v$. Helm recognized the "harm caused or threatened to the victim or society" as one factor relevant to the comparison of offenses, it did not indicate it was thereby dispensing with the need for proof. 463 U.S. 277,292 (1983). 
number of courts ${ }^{214}$ and scholars. ${ }^{215}$ When viewed through the lens of the proportionality principle, perhaps the most efficacious purpose of the reasonable relationship rule is to prevent such "overkill" where a single defendant is threatened with pumitive damages in numerous suits based on one product or course of conduct. ${ }^{216}$

Devising a scheme that will both encourage socially desirable litigation and protect defendants (and other potential plaintiffs) from excessive awards may prove difficult. ${ }^{217}$ The Constitution, however, demands careful attention to the dangers inherent in expanding the context of litigation beyond the dispute between the parties. Deterrence is not an unlimited interest; any restriction on the power to punish limits the ability to deter undesirable behavior. In this sense, the constitutional prohibition of excessive fines represents an acknowledgment that the power of government is not unlimited. The interests of the plaintiff and society in punishing and deterring culpable conduct must be balanced against the right of defendants to (and the interest of society in) the protections provided by basic principles of justice. While it may be permissible im some circumstances to impose punitive damages that are unrelated to the injury suffered by the plaintiff, such awards should be the exception rather than the rule, and should be subject to careful judicial scrutiny.

214. See, e.g., Jackson v. Johns-Manville Sales Corp., 727 F.2d 506, 526-27 (5th Cir. 1984) (punitive damages found inappropriate in asbestos litigation), vacated in part on reh'g en banc, 750 F.2d 1314 (5th Cir. 1985); Roginsky v. Richardson-Merrell, Inc., 378 F.2d 832, 839-41 (2d. Cir. 1967). But see Palmer v. A.H. Robins Co., 684 P.2d 187, 216 (Colo. 1984) (brushing aside defendant's "punitive overkill" argument with the observation that there was no evidence of past punitive arvards that might render the present award excessive). The Palmer court did not address the question of how many other women injured by the Dalkon Shield would also be entitled to $\$ 6.2$ million in punitive damages.

215. Professor Jeffries focuses his argument for applying the excessive fines clause to punitive damages on the fundamental unfairness of "repetitive punitivc awards for a single course of conduct." Jeffries, supra note 1, at 140; see also Owen, supra note 10, at 1320 (observing a "significant risk that a manufacturer will be severely over-punished by scores or even hundreds of judgments for both compensatory and punitive damages"); Seltzer, supra note 31, at 55 ("aggregate amount of multiple awards . . can reach ... fundamentally unfair and destructive [levels]").

216. See, e.g., Hoffman v. Sterling Drug, Inc., 374 F. Supp. 850, 856 (M.D. Pa. 1974) (punitive damages, "if any, must be a reasonable sum in relation to the defendant's conduct vis-a-vis the plaintiff"). The court rejected the "plaintiff's rationale [that] each injured consumer . . . could individually recover on behalf of 'society' to punish the affront," holding instead that each "consumer showing a bona fide injury may, if the evidence warrants, collect his reasonable proportion of the punitive damages the defendant owes to "society." II. at 857.

217. One proposed solution to this dilemma is making class action suits more available in products liability and other multiple tort cases. See Seltzer, supra note 31, at 61-91. Judge Friendly apparently envisioned some such procedure to resolve the problems of mass tort litigation that he recognized in Roginsky, 378 F.2d at 839 n.11, although he concluded that federal legislation would be required to implement it. Id. Recent attempts to create class actions for multiple punitive damage claims have encountered numerous substantive and procedural obstacles. See cases collected in D. Laycock, Modern American Remedies: Cases and Materials 608-09 (1985); id. at 44-45 (Supp. 1986). 


\section{Substance Over Form}

The Constitution does not require that states mechanically apply a specific ratio of punitive to compensatory damages. As with the scrutiny of criminal punishments, states should be given substantial leeway for experimentation and consideration of the facts of individual cases. ${ }^{218}$ The principle underlying the reasonable relationship rule, however, is closely related to the fundamental principle of the eighth amendment. The doctrine of proportionality, as delineated by the Supreme Court, requires that offenses be compared according to objective measures of culpability and harm, and that more serious offenders receive proportionally harsher penalties than less serious offenders. A state cannot objectively measure the gravity of an offense without some reference to the damages caused by the wrongful conduct. The reasonable relationship rule is one means of expressing this requirement.

Observance of the reasonable relationship rule as a means of applying the principle of proportionality does not mean, however, that merely stating the rule will ensure the constitutionality of a punitive damage award. Other factors, such as an overemphasis on the wealth of the defendant, may taint the verdict. ${ }^{219}$ In addition, the rule may be applied arbitrarily, such that it does not serve its essential function of distinguishing offenses according to degrees of seriousness. ${ }^{220}$ Therefore, any constitutional analysis of standards by which a state assesses punitive damages should focus on substance rather than form. The question is whether the state has made a reasonable effort to ensure that punishments are proportional to the offenses for which they are imposed.

\section{CONCLUSION}

There are no simple answers to the questions raised by the imposition of punitive damages in contemporary society. This Comment has attempted to develop an analytical framework for assessing when a punitive damage award is unconstitutionally excessive. Because punitive damages are the functional equivalent of fines, the excessive fines clause of the eighth amendment should be held to limit the size of such awards. Moreover, the principle of proportionality on which the eighth amendment is founded requires that punitive damages, like other fines, be awarded in amounts that are proportionate to the gravity of the offenses

218. See supra notes 123-26 and accompanying text. The greatest deference is due to legislativc judgments of the relative gravity of offenses and appropriate penalties. Where penalties are assessed in the absence, or in derogation, of such judgments, stricter scrutiny is justified. Id.

219. Indeed, any time the defendant's wealth is allowed into evidence before the jury has determined whether punitive damages are justified, there is a serious danger of prejudicing the judgment. See supra notes 149-74 and accompanying text.

220. See supra notes $197-98$ and accompanying text. 
for which they are imposed. In scrutinizing state punitive damage assessments, courts should employ the guidelines developed by the Supreme Court in Solem. . . Helm, ${ }^{221}$ which focus on objective measures of culpability and harm.

Evaluated from the standpoint of the principle of proportionality and the Solem criteria, the prevailing practices of most American jurisdictions appear constitutionally suspect. The standard applied by the Mississippi courts in the Bankers Life case presently before the U.S. Supreme Court is clearly inadequate, particularly because of its excessive emphasis on the wealth of the defendant. The three-prong test of the California courts, although more balanced in its approach, does not sufficiently ensure that punitive awards are proportionate to the offenses for which they are imposed. What is needed in these and other jurisdictions are carefully drafted statutes that establish categories and levels of punishable conduct, and that provide guidelines for imposing penalties according to the relative gravity of such conduct.

Lyndon F. Bittle*

221. 463 U.S. 277 (1983).

* B.A. 1971, University of California, Santa Barbara; third-year student, Boalt Hall School of Law, University of California, Berkeley. 
